Mycologia, 97(2), 2005, pp. 375-395.

(C) 2005 by The Mycological Society of America, Lawrence, KS 66044-8897

\title{
Classification of the guava wilt fungus Myxosporium psidii, the palm pathogen Gliocladium vermoesenii and the persimmon wilt fungus Acremonium diospyri in Nalanthamala
}

\author{
H.-J. Schroers ${ }^{1}$ \\ Centraalbureau voor Schimmelcultures, Fungal \\ Biodiversity Centre (CBS), Utrecht, The Netherlands
}

M.M. Geldenhuis

M.J. Wingfield

Department of Microbiology and Plant Pathology,

Forestry and Agricultural Biotechnology Institute

(FABI), University of Pretoria, South Africa

M.H. Schoeman

Institute for Tropical and Subtropical Crops, Nelspruit, South Africa

Y.-F. Yen

W.-C. Shen

Department of Plant Pathology and Microbiology, National Taiwan University, Taipei, Taiwan

B.D. Wingfield

Department of Genetics, Forestry and Agricultural Biotechnology Institute (FABI), University of Pretoria, South Africa

Abstract: Psidium guajava wilt is known from South Africa, Malaysia and Taiwan. The fungus causing this disease, Myxosporium psidii, forms dry chains of conidia on surfaces of pseudoparenchymatous sporodochia, which develop in blisters on bark. Similar sporodochia are characteristic of Nalanthamala madreeya, the type species of Nalanthamala. Nalanthamala, therefore, is the appropriate anamorph genus for Myxosporium psidii, while Myxosporium is a nomen nudum (based on $M$. croceum). For $M$. psidii the combination Nalanthamala psidii is proposed. Nalanthamala psidii, the palm pathogen Gliocladium (Penicillium) vermoesenii, another undescribed anamorphic species from palm, two species of Rubrinectria and the persimmon pathogen Acremonium diospyri are monophyletic and belong to the Nectriaceae (Hypocreales) based on partial nuclear large subunit ribosomal DNA (LSU rDNA) analyses. Rubrinectria, therefore, is the teleomorph of Nalanthamala, in which the anamorphs are classified as N. vermoesenii, N. diospyri or Nalanthamala sp. Nalanthamala squamicola, the only other Nalanthamala species, has affin-

\footnotetext{
Accepted for publication 10 May 2004.

${ }^{1}$ Corresponding author. Current address: Agricultural Institute of Slovenia, Hacquetova 17, p.p. 2553, 1001 Ljubljana, Slovenia. Email: Hans.Schroers@kis.si
}

ities with the Bionectriaceae and is excluded from this group. Rubrinectria/Nalanthamala species form dimorphic conidiophores and conidia in culture. Fusiform, cylindrical, or allantoid conidia arise in colorless liquid heads on acremonium-like conidiophores; ovoidal conidia with somewhat truncated ends arise in long, persistent, dry chains on penicillate conidiophores. No penicillate but irregularly branched conidiophores were observed in $N$. diospyri. Conidia of $N$. psidii that are held in chains are shorter than those of $N$. madreeya, of which no living material is available. Nalanthamala psidii and N. diospyri are pathogenic specifically to their hosts. They form pale yellow to pale orange or brownish orange colonies, respectively, and more or less white conidial masses. Most strains of Rubrinectria sp., Nalanthamala sp. and $N$. vermoesenii originate from palm hosts, form mostly greenish or olive-brown colonies and white-to-salmon conidial masses. They form a monophyletic clade to which Nalanthamala psidii and $N$. diospyri are related based on analyses of the internal transcribed spacer regions and 5.8S rDNA (ITS rDNA), LSU rDNA, and partial $\beta$-tubulin gene. Few polymorphic sites in the ITS rDNA and $\beta$-tubulin gene indicate that Nalanthamala psidii comprises two lineages, one of which has been detected only in South Africa.

Key words: $\beta$-tubulin gene, internal transcribed spacer, Nalanthamala madreeya, Nalanthamala squamicola, Nectriaceae, nuclear large subunit ribosomal DNA, phylogeny, systematics, wilt disease

\section{INTRODUCTION}

Psidium guajava (guava) wilt is a serious disease in Taiwan (Kurosawa 1926, Leu et al 1979), South Africa (Grech 1985, Anonymous 1987, Grech 1990, Schoeman et al 1997) and Malaysia (Schoeman unpubl). The disease is characterized by a rapid or a slow decline of trees and the development of red-brown blisters on trunks and branches consisting of sporodochia and conidial masses of the pathogen and the outer cortex of the host (Schoeman et al 1997).

The guava wilt fungus was described as Myxosporium psidii Sawada \& Kurosawa (Kurosawa 1926) based on acervuli-like conidiomata, penicillate and simple branched conidiophores, as well as two dis- 
tinct types of conidia, one of which is formed in linear chains. The generic classification of $M$. psidii is unsettled. The genus Myxosporium Link based on $M$. croceum (Pers. : Fr.) Link (= Naemaspora crocea Pers.) was rejected by von Höhnel (1915) and regarded as a nomen nudum by Sutton (1977). Independently of Kurosawa (1926), the guava wilt fungus has been linked with Septofusidium W. Gams (Grech 1985) but S. elegantulum (Pidopl.) W. Gams, the type species of Septofusidium, hardly grows in culture (Gams 1971) and no living strain of the type species is available. The guava wilt fungus was also compared with Gliocladium (Penicillium) vermoesenii (Biourge) Thom (Schoeman et al 1997) and Clonostachys (as "Gliocladium roseum Bainier series") (Thom 1930). According to current concepts, however, neither Gliocladium nor Clonostachys could accommodate the guava wilt fungus or G. vermoesenii (Seifert 1985, Schroers et al 1999). Penicillium vermoesenii Biourge was described as forming salmon-colored coremia, penicillate conidiophores and ellipsoidal conidia of 5-7.5 $\times 3-4$ $\mu \mathrm{m}$ arranged in chains and as being pathogenic to Areca L. (Biourge 1923). Its identity is supported by an ex-type strain (Thom 1930, Raper and Thom 1949). Thom (1930) mentioned an additional conidial form produced by $P$. vermoesenii and transferred it to Gliocladium Corda. As a cause of necrosis and blight of palms, it is known from the United States (Bliss 1938, Reynolds 1964), Europe (López-Llorca and Orts 1994), and Australia (Anonymous 2001) and was described as occurring worldwide (Aragaki et al 1991) or as widespread (Farr et al 1989).

Phylogenetic analyses of various other fungi suggested that linear, persistent or caducous chains of conidia or heads of liquid to slimy conidial masses formed on penicillate conidiophores (penicilliumlike or gliocladium-like conidiophores, respectively) have evolved in unrelated groups of fungi (Berbee et al 1995, Ogawa et al 1997, Rehner and Samuels 1994) and that both forms even can occur in the same monophyletic group (Haugland et al 2001).

Nalanthamala was introduced for N. madreeya Subramanian. It was characterized by pseudoparenchymatous sporodochia formed on an unidentified dead stem, phialides formed at the surface of these sporodochia and elliptical to oval or lenticular conidia arranged in chains (Subramanian 1956). Nalanthamala madreeya apparently has not been cultured and Nalanthamala is reported rarely in literature. Fusidium squamicola Berk. \& Broome was placed in $\mathrm{Na}$ lanthamala because a strain resembling the type of $F$. squamicola formed sporodochia and chains of conidia in culture (Gams 1975). No teleomorph is known for N. madreeya, M. psidii, G. vermoesenii and $N$. squamicola (Berk. \& Broome) W. Gams, but the ex- ascospore isolate of Macbridella olivacea Seaver, now Rubrinectria olivacea (Seaver) Rossman \& Samuels (Rossman et al 1999), produced conidia in dry chains similar to those formed by G. vermoesenii (Seaver 1910, Samuels 1973).

Acremonium diospyri (Crandall) W. Gams forms masses of conidia beneath the bark of its host Diospyros virginiana, on which it causes a serious wilt (Crandall and Baker 1950). Durrell (1963) observed chains of conidia, and Gams (1971) described two different kinds of conidia formed by $A$. diospyri. Benade et al (1991) observed morphological similarities between $A$. diospyri and the guava pathogen and distinguished both species based on their cellular longchain fatty acid composition and growth rate in culture.

In this study, morphological characters and DNA sequences of the partial $\beta$-tubulin gene exons and introns and the ribosomal gene cluster were used to characterize, both taxonomically and phylogenetically, M. psidii, G. vermoesenii, A. diospyri and ascospore isolates of Rubrinectria. To infer their higher-rank phylogeny, sequences of the LSU rDNA of these taxa were compared with those of other, mainly hypocrealean taxa forming conidial chains and penicillate conidiophores (TABLE I).

\section{MATERIALS AND METHODS}

Fungal strains and herbarium specimens.-Strains of M. psidii were isolated from diseased trees in South Africa and Malaysia (TABLE II); a strain from Taiwan was collected and isolated by Y.-F. Yen (National Taiwan University, Taipei, Taiwan) and Yu-ming Ju (Institute of Botany, Academia Sinica, Taipei, Taiwan), respectively. Twig fragments of dead Psidium guajava trees containing sporodochia of $M$. psidii were obtained from Barry Manicom (ARC-ITSC, Nelspruit, South Africa); the type specimen of $M$. psidii was obtained from the herbarium of the National Taiwan University. Additional strains of $M$. psidii or strains and herbarium specimens of other included species were obtained from the CBS Fungal Biodiversity Centre (CBS, Utrecht, Netherlands), Agro-industrial Fungi \& Yeasts Collection (MUCL, Louvain-la-Neuve, Belgium) and Systematic Botany and Mycology Laboratory (BPI, Beltsville, Maryland). The strains were maintained at CBS and the Forestry and Agricultural Biotechnology Institute (FABI), University of Pretoria, South Africa (CMW).

Morphological examinations.-Bark from 3-5 cm thick dead guava twigs was placed in moist chamber. After $3 \mathrm{~d}$, portions of developing conidial chains were removed and streaked on oatmeal agar (OA), containing streptomycin and penicillin (Gams et al 1998a), with a sterile glass needle. Longitudinal sections of sporodochia formed beneath blisters were prepared as described elsewhere (Schroers 2001). Synthetic nutrient-poor agar (SNA) with $1 \times 3 \mathrm{~cm}$ pieces of filter-paper (Nirenberg 1976), potato-dextrose agar (PDA, 
TABLE I. Selected hypocrealean taxa forming linear, persistent, but disconnected or imbricate condidial chains

\begin{tabular}{|c|c|c|c|c|c|}
\hline Genus & Family & $\begin{array}{c}\text { Type of } \\
\text { conidiophore }\end{array}$ & $\begin{array}{l}\text { Shape of catenate } \\
\text { conidia }\end{array}$ & $\begin{array}{l}\text { Synanamorph } \\
\text { with conidial } \\
\text { heads }\end{array}$ & References \\
\hline \multicolumn{6}{|c|}{ Taxa forming linear, persistent conidial chains } \\
\hline $\begin{array}{l}\text { Acremonium "sect. Simplex" W. } \\
\text { Gams, "Terricola series", teleo- } \\
\text { morph unknown }\end{array}$ & $\begin{array}{l}\text { partly Bionectri- } \\
\text { aceae or un- } \\
\text { known }\end{array}$ & acremonium-like & \pm fusiform & not known & Gams (1971) \\
\hline $\begin{array}{l}\text { Geosmithia J. Pitt, teleomorph } \\
\text { unknown }\end{array}$ & Bionectriaceae & penicillium-like & ellipsoidal & not known & $\begin{array}{l}\text { Pitt }(1979) \\
\text { Ogawa et al } \\
(1997)\end{array}$ \\
\hline $\begin{array}{l}\text { Cordyceps (Fr.) Link, anamorph } \\
\text { Isaria Fr. }\end{array}$ & Clavicipitaceae & penicillium-like & $\begin{array}{l}\text { ellipsoid, subglo- } \\
\text { bose, fusiform }\end{array}$ & not known & Samson (1974) \\
\hline $\begin{array}{l}\text { Torrubiella luteorostrata Zimm., } \\
\text { anamorph Paecilomyces cinna- } \\
\text { momeus (Petch) Samson \& } \\
\text { W. Gams }\end{array}$ & Clavicipitaceae & penicillium-like & fusiform & not known & $\begin{array}{l}\text { Hywel-Jones } \\
\quad(1993)\end{array}$ \\
\hline $\begin{array}{l}\text { Albonectria Rossman \& Samuels; } \\
\text { anamorph Fusarium Link }\end{array}$ & Nectriaceae & $\begin{array}{l}\text { typically verticil- } \\
\text { late }\end{array}$ & ovoidal & $\begin{array}{l}\text { generally pres- } \\
\text { ent, sporodo- } \\
\text { chial }\end{array}$ & $\begin{array}{l}\text { Rossman et al } \\
\text { (1999), Ger- } \\
\text { lach and Ni- } \\
\text { renberg } \\
\text { (1982) }\end{array}$ \\
\hline $\begin{array}{l}\text { Gibberella fujikuroi species com- } \\
\text { plex, anamorph Fusarium } \\
\text { Link }\end{array}$ & Nectriceae & $\begin{array}{l}\text { acremonium-like } \\
\text { or irregularly } \\
\text { branched }\end{array}$ & clavate-fusiform & $\begin{array}{l}\text { generally pres- } \\
\text { ent }\end{array}$ & $\begin{array}{l}\text { Nirenberg and } \\
\text { O’Donnell } \\
(1998)\end{array}$ \\
\hline $\begin{array}{l}\text { Rubrinectria Rossman \& Samuels, } \\
\text { anamorph Nalanthamala Sub- } \\
\text { ramanian }\end{array}$ & Nectriaceae & penicillium-like & ovoidal & $\begin{array}{l}\text { generally pres- } \\
\text { ent }\end{array}$ & this paper \\
\hline $\begin{array}{l}\text { Viridispora Samuels \& Rossman, } \\
\text { anamorph Penicillifer Emden }\end{array}$ & Nectriaceae & acremonium-like & $\begin{array}{l}\text { ellipsoid to sub- } \\
\text { fusiform, typi- } \\
\text { cally 1-septate }\end{array}$ & not known & Samuels (1989) \\
\hline \multicolumn{6}{|c|}{ Taxa forming imbricate conidial chains } \\
\hline $\begin{array}{l}\text { Bionectria Speg., anamorph Clon- } \\
\text { ostachys Corda }\end{array}$ & Bionectriaceae & gliocladium-like & $\begin{array}{l}\text { ovoidal, slightly } \\
\text { curved, hilum } \\
\text { laterally dis- } \\
\text { placed }\end{array}$ & $\begin{array}{l}\text { generally pres- } \\
\text { ent }\end{array}$ & Schroers (2001) \\
\hline $\begin{array}{l}\text { "Nectria", anamorph Marian- } \\
\text { naea Arnaud ex Samson }\end{array}$ & Nectriaceae & $\begin{array}{l}\text { verticillium to } \\
\text { gliocladium- } \\
\text { like }\end{array}$ & $\begin{array}{l}\text { ovoidal, slightly } \\
\text { curved, hilum } \\
\text { laterally dis- } \\
\text { placed }\end{array}$ & $\begin{array}{l}\text { present in some } \\
\text { of the species }\end{array}$ & $\begin{array}{l}\text { Samson (1974), } \\
\text { Samuels and } \\
\text { Seifert (1981) }\end{array}$ \\
\hline
\end{tabular}

Difco, Sparks, Nevada) and OA in $9 \mathrm{~cm}$ diam Petri dishes were used. Growth was measured from $5 \mathrm{~d}$ old PDA cultures incubated in the dark at 20, 25, 30 and $33 \mathrm{C}$ using blocks of $3 \mathrm{~mm}^{2}$ excised from young parts of OA colonies as inocula. Measurements of microscopic characters, obtained from lactic acid mounts, were made from 5-12 d old SNA or OA colonies incubated at $20 \mathrm{C}$ in the dark. Ranges of measurements are reported as described elsewhere (Schroers 2001). Macroscopic characters and colony colors were described from $14 \mathrm{~d}$ or 3-4 wk old PDA or OA cultures incubated at $20 \mathrm{C}$ in the dark or under continuous nearUV light (400-315 nm) (Sylvania blacklight-blue). Color names are from Kornerup and Wanscher (1978). Low temperature scanning electron microscopy (SEM) was done as described by Dijksterhuis et al (1991) using sporulating ma- terial on squares smaller than $0.5 \mathrm{~cm}^{2}$ excised from OA cultures.

DNA isolation, amplification and sequencing.-Mycelium for DNA extraction was grown and harvested as described by Rehner and Samuels (1994). DNA was extracted using the FastDNA ${ }^{\circledR}$ Kit (BIO 101 Inc., Carlsbad, California). These primer pairs were used for PCR amplifications: T1/T22 (O'Donnell and Cigelnik 1997) for the partial $\beta$-tubulin gene, V9G/LR5 (de Hoog and Gerrits van den Ende 1998, Vilgalys and Hester 1990) for the partial LSU rDNA, V9G/ LR5 or ITS1/ITS4 (White et al 1990) for the ITS rDNA. A PCR System 9700 (PE Applied Biosystems) using ramp speeds of the PCR System 9600 was used for amplification using these programs: an initial denaturation step at $94 \mathrm{C}$ 


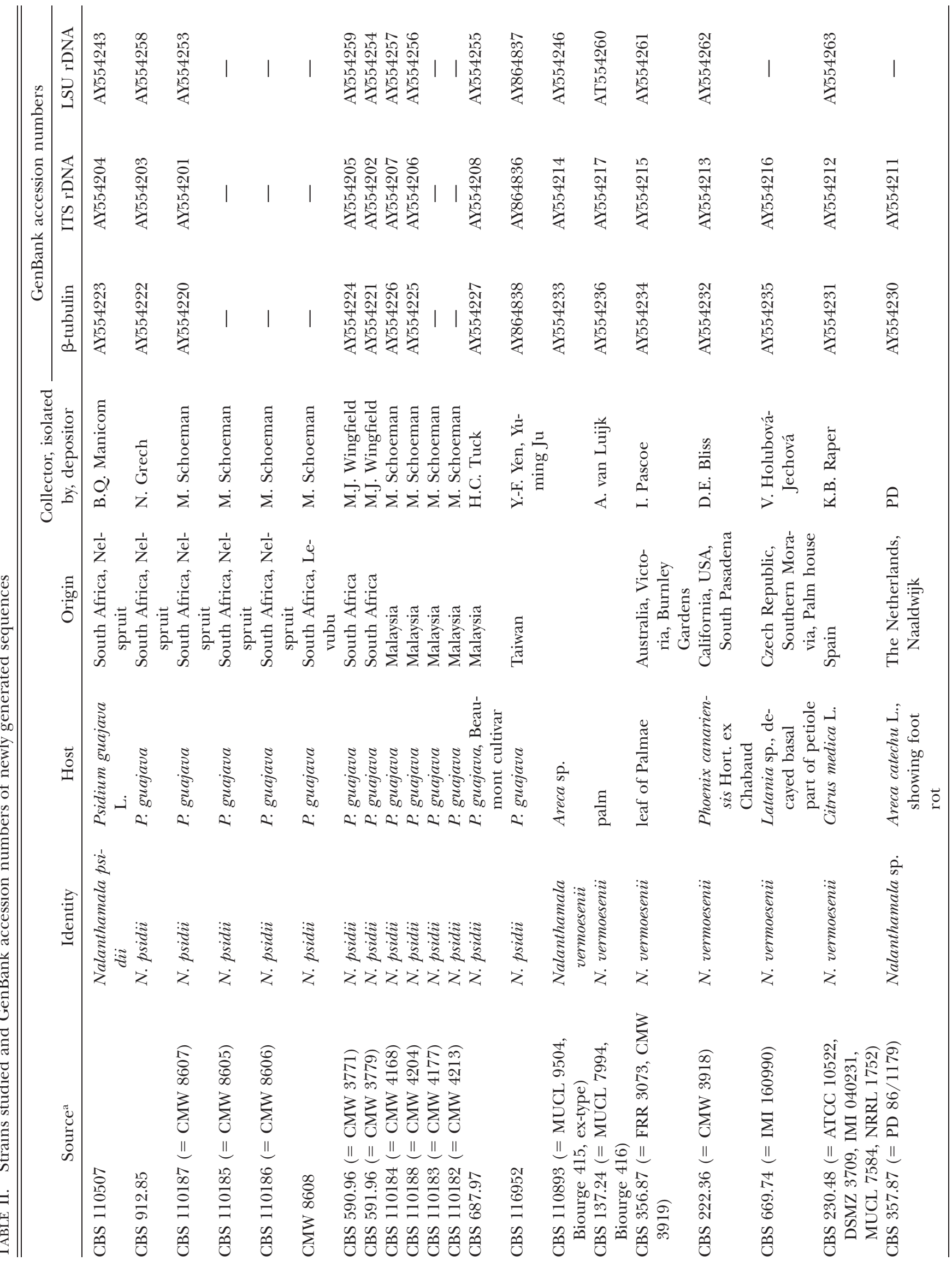


Schroers ET AL: TAXONOMY OF NALANTHAMALA

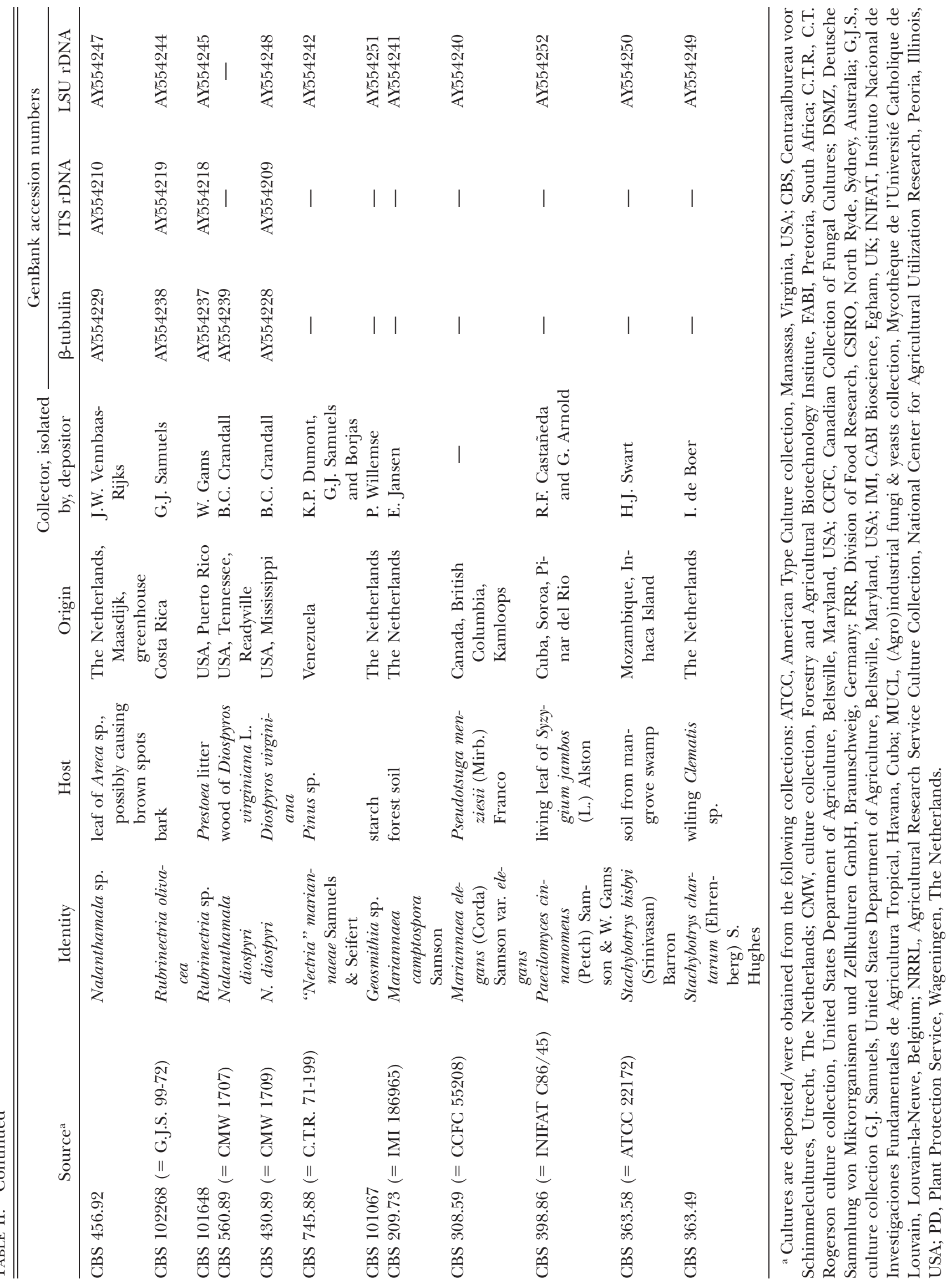


for $2 \mathrm{~min}, 35$ cycles of $94 \mathrm{C}$ for $35 \mathrm{~s}, 58$ (for T1/T22) or $55 \mathrm{C}$ (for V9G/LR5 and ITS1/ITS4) for $50 \mathrm{~s}$, $72 \mathrm{C}$ for 2 $\mathrm{min}$, and a final extension at $72 \mathrm{C}$ for $6 \mathrm{~min}$. The vials of $50 \mu \mathrm{L}$ contained $1 \mu \mathrm{L}$ genomic DNA extract, 25 pmol of each of the primers, $200 \mu \mathrm{mol}$ of each of the dNTPs (Amersham Biosciences), $1 \mathrm{U}$ of Taq polymerase (Super Taq, HT Biotechnology, UK), and $1 \times$ standard PCR buffer supplied with the Taq polymerase. PCR fragments were purified using the GFX ${ }^{\circledR}$ purification kit (Amersham Pharmacia Biotech Inc., Roosendaal, Netherlands). The amplicons were sequenced with the BigDye Terminator Cycle Sequencing Kit (Applied Biosystems, Foster City, California) and analyzed on an ABI Prism 3700 (Applied Biosystems) by using the standard conditions recommended by the vendor. The primers used in the sequence reactions were ITS1, ITS4, LR5, NL1 or NL4 (O'Donnell 1993) for the rDNA and T1 or T2 (O'Donnell and Cigelnik 1997) for the partial $\beta$-tubulin gene.

Sequence analyses.-Newly generated (TABLE II) and published sequences were aligned using Clustal X 1.81 (Jeannmougin et al 1998). The alignments were adjusted manually. An LSU rDNA dataset comprised hypocrealean taxa, including members of the Clavicipitaceae, Penicillium expansum Link, the type species of the genus Penicillium Link (Eurotiales), and Verticillium dahliae Kleb. (Phyllachorales), of which the latter was used as outgroup. A region containing multiple gaps and its flanking sides (bp 50-60 of the alignment) was excluded from the analyses of this dataset. Another dataset comprising partial LSU rDNA, complete ITS rDNA and partial $\beta$-tubulin gene intron and exon sequences was used to analyze the relationship of strains of the guava pathogen and its close relatives using Bionectria/ Clonostachys (Bionectriaceae) as outgroup and Gibberella Sacc./Fusarium (Nectriaceae) as sister group. Incomplete 3 - and $5^{\prime}$-parts of sequences were coded as missing characters. Phylogenetic relationships were estimated from the aligned sequences by the maximum parsimony criterion as implemented in PAUP 4.0b10 (Swofford 2002). Heuristic searches were performed using parsimony informative, unordered and equally weighted characters; branch robustness was tested by 1000 search replications, each on bootstrapped datasets. Gaps were treated as missing characters. Starting tree(s) were obtained via stepwise, random, $100 \times$ $(10 \times$ in bootstrap analyses) repeated sequence addition. A maximum number of 1000 trees were allowed.

Sequence data.-Newly generated sequences (TABLE II) and the alignments were deposited in GenBank (www.ncbi. nlm.nih.gov) and TreeBase (www.treebase.org), respectively. These taxa and published sequences were included in the analyses: Acremonium alternatum Link per S.F. Gray, U57349 (Glenn and Bacon unpubl); Albonectria albosuccinea (Pat.) Rossman \& Samuels, U34554 (O'Donnell and Cigelnik 1997); A. rigidiuscula (Berk. \& Broome) Rossman \& Samuels, U88104 (O’Donnell 1993); Bionectria ochroleuca (Schw.) Schroers \& Samuels, U00750 (Rehner and Samuels 1994), AF210686, AF358159 (Schroers 2001); B. ralfsii (Berk. \& Broome) Schroers \& Samuels, AF210676 (Schroers 2001); B. zelandiaenovae Schroers, AF210684 (Schroers 2001); Calonectria morganii Crous et al, U17409
(Rehner and Samuels 1995); C. pyrochroa (Desm.) Sacc., U88097 (O'Donnell 1993); Clonostachys miodochialis Schroers, AF358210, AF210674 (Schroers 2001); Epichloë typhina (Pers. : Fr.) Tulasne \& C. Tulasne, U17396 (Rehner and Samuels 1995); Fusarium fujikuroi Nirenberg, U34415, U34528, U34557 (O'Donnell and Cigelnik 1997, O'Donnell et al 1998); F. verticillioides (Sacc.) Nirenberg, U34526 (O’Donnell and Cigelnik 1997); Geosmithia lavendula (Raper \& Fennell) Pitt, D88325 (Ogawa et al 1997); G. putterillii (Thom) Pitt, D88326 (Ogawa et al 1997); Gibberella zeae (Schw.) Petch, U34436, U34549, U34578 (O'Donnell and Cigelnik 1997); Haematonectria haematococca (Berk. \& Broome) Samuels \& Nirenberg, L36623 (O’Donnell and Gray 1995); Hydropisphaera arenula (Berk. \& Broome) Rossman \& Samuels, U88121 (O'Donnell 1993); H. erubescens (Desm.) Rossman \& Samuels, AF193228 (Rossman et al 2001); H. peziza (Tode : Fr.) Dumort., U88131 (O’Donnell 1993); Hypocrea lutea (Tode) Petch, U00739 (Rehner and Samuels 1994); H. schweinitzii (Fr.) Sacc., U47833 (Spatafora unpubl); Hypomyces odoratus G. Arnold, AF160240 (Põldmaa et al 1999); Lecanicillium lecanii (Zimm.) Zare \& W. Gams, U17421 (Rehner and Samuels 1995); Metarhizium anisopliae (Metschn.) Sorok., AF339529 (Sung et al 2001); Myrothecium inundatum Tode : Fr., AF193236 (Rossman et al 2001); "Nalanthamala" squamicola, AF373281 (Bills et al 2002); Nectria cinnabarina (Tode : Fr.) Fr., U00749 (Rehner and Samuels 1994); N. pseudotrichia Berk. \& M.A. Curtis, U17410 (Rehner and Samuels 1995); Nectriopsis sporangiicola (Samuels) Samuels, U00753 (Rehner and Samuels 1994); N. violacea (Schmidt: Fr.) Maire, AF193242 (Rossman et al 2001); Neocosmospora vasinfecta E.F. Smith, U47836 (Spatafora unpubl); Neonectria radicicola (Gerlach \& L. Nilsson) Mantiri \& Samuels, U17415 (Rehner and Samuels 1995); Neotyphodium coenophialum (Morgan-Jones \& W. Gams) Glenn et al, U57681 (Glenn and Bacon unpubl); Peethambara sundara Subramanian \& D.J. Bhat, AF193245 (Rossman et al 2001); Penicillium expansum, AF003359 (Seifert and Louis-Seize unpubl); Roumegueriella rufula (Berk. \& Broome) Malloch \& Cain, U00754 (Rehner and Samuels 1994); Sphaerostilbella aureonitens (Tulasne) Seifert et al, AF160246 (Põldmaa et al 1999); Stachybotrys echinata (Rivolta) G. Smith, AF081470 (Haugland et al 2001); Stanjemonium grisellum W. Gams et al, AF049171 (Gams et al 1998b); Torrubiella luteorostrata, AF327380 (Artjariyasripong et al 2001); Verticillium dahliae, U17425 (Rehner and Samuels 1995); Viridispora diparietispora (J.H. Miller et al) Samuels \& Rossman, U17411 (Rehner and Samuels 1995).

\section{RESULTS}

Myxosporium psidii, G. vermoesenii, A. diospyri, for which the combinations Nalanthamala psidii, N. vermoesenii and $N$. diospyri are proposed in this paper, as well as a Nalanthamala sp. and two Rubrinectria species are closely related and present distinct phylogenetic taxa (FIGS. 1, 2). Sporodochia and conidia formed by $N$. psidii from Taiwan and South Africa are indistinguishable (Kurosawa 1926; FIGS. 3-28). Similar characters but longer conidia are also formed 


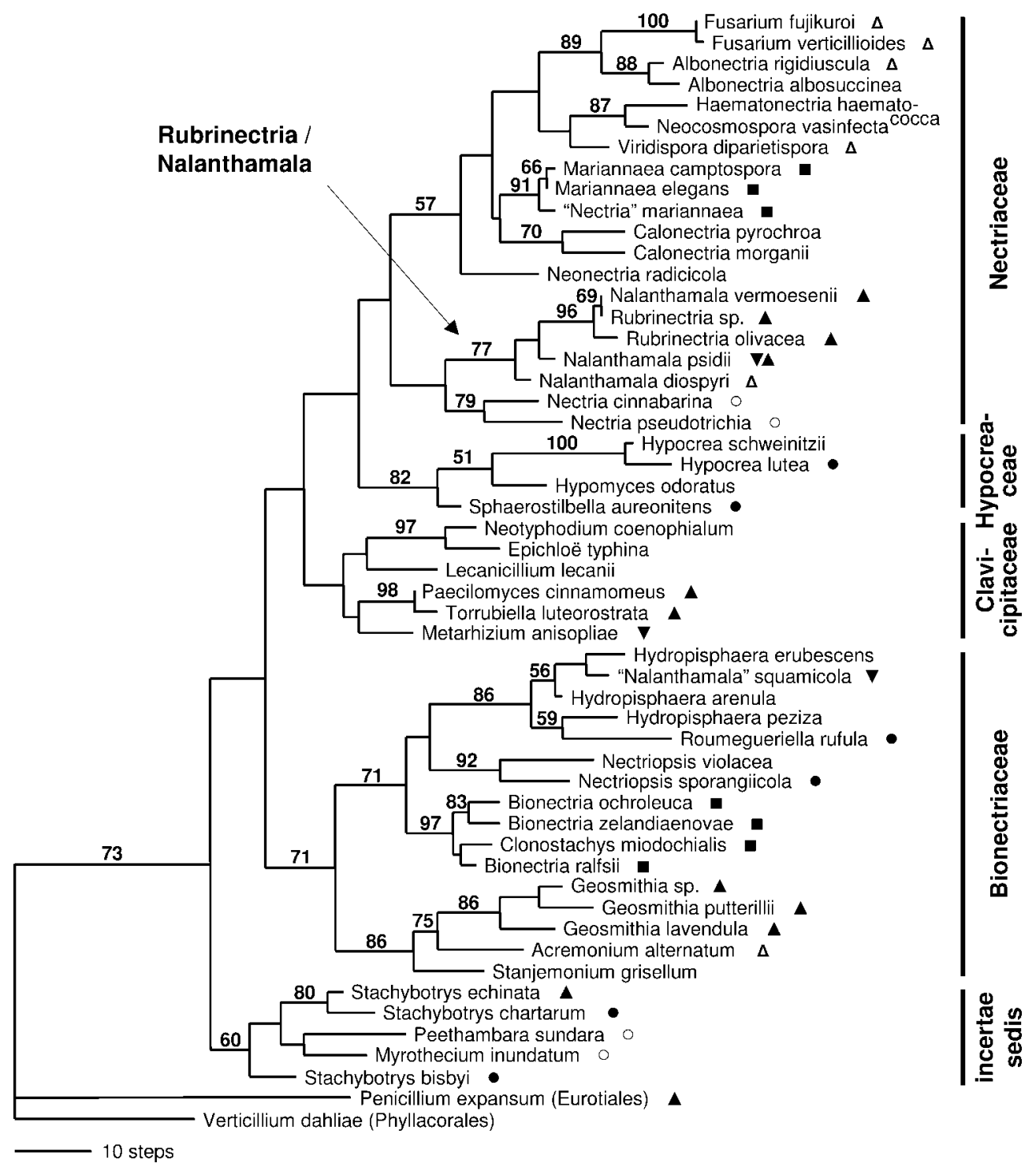

FIG. 1. One of seven equally parsimonious phylograms inferred from partial LSU rDNA sequences. Bootstrap intervals from 1000 replicates are indicated above nodes. Symbols (right of the tree) indicate taxa forming linear chains of conidia on acremonium-like or branched but not penicillately branched conidiophores $(\triangle)$, penicillately branched conidiophores $(\boldsymbol{\Delta})$ or conidiomata $(\boldsymbol{\nabla})$; mucous heads or slimy masses of conidia on penicillately branched conidiophores $(\mathbf{O})$ or conidiomata $(\bigcirc)$; imbricate chains of conidia on penicillately branched conidiophores or conidiomata ( $\square$ ). The Rubrinectria/ Nalanthamala clade forms a moderately supported monophyletic clade among other genera of the Nectriaceae. CI $=0.319$; $\mathrm{RI}=0.641$.

by N. madreeya, the type of Nalanthamala (Subramanian 1956). In pure cultures, N. psidii (FIGS. 1128), N. vermoesenii (FIGS. 29-43), the two Rubrinectria species, the undescribed anamorphic Nalanthamala sp. and $N$. diospyri (FIGS. 44-59) form similar dimorphic conidia, observed in all species, and dimorphic conidiophores, formed in all species except $N$. diospyri. Nalanthamala psidii differs from N. vermoesenii, N. diospyri, Nalanthamala sp. and Rubrinectria sp. mainly in macroscopic characters such as growth rates of colonies, pigmentation of conidial masses and pigmentation of colonies as well as in pathogenicity and host spectrum (TABLE III).

Sequence data analyses.-Heuristic parsimony analyses of LSU rDNA aligned sequences (536 bp alignment positions containing 126 parsimony informative characters, PIC) resulted in seven equally most-parsimonious trees 645 steps in length, with a consistency index (CI) of 0.319 and a retention index (RI) of 0.641 . The seven equally parsimonious trees showed the same overall branching topology. Penicillium ex- 


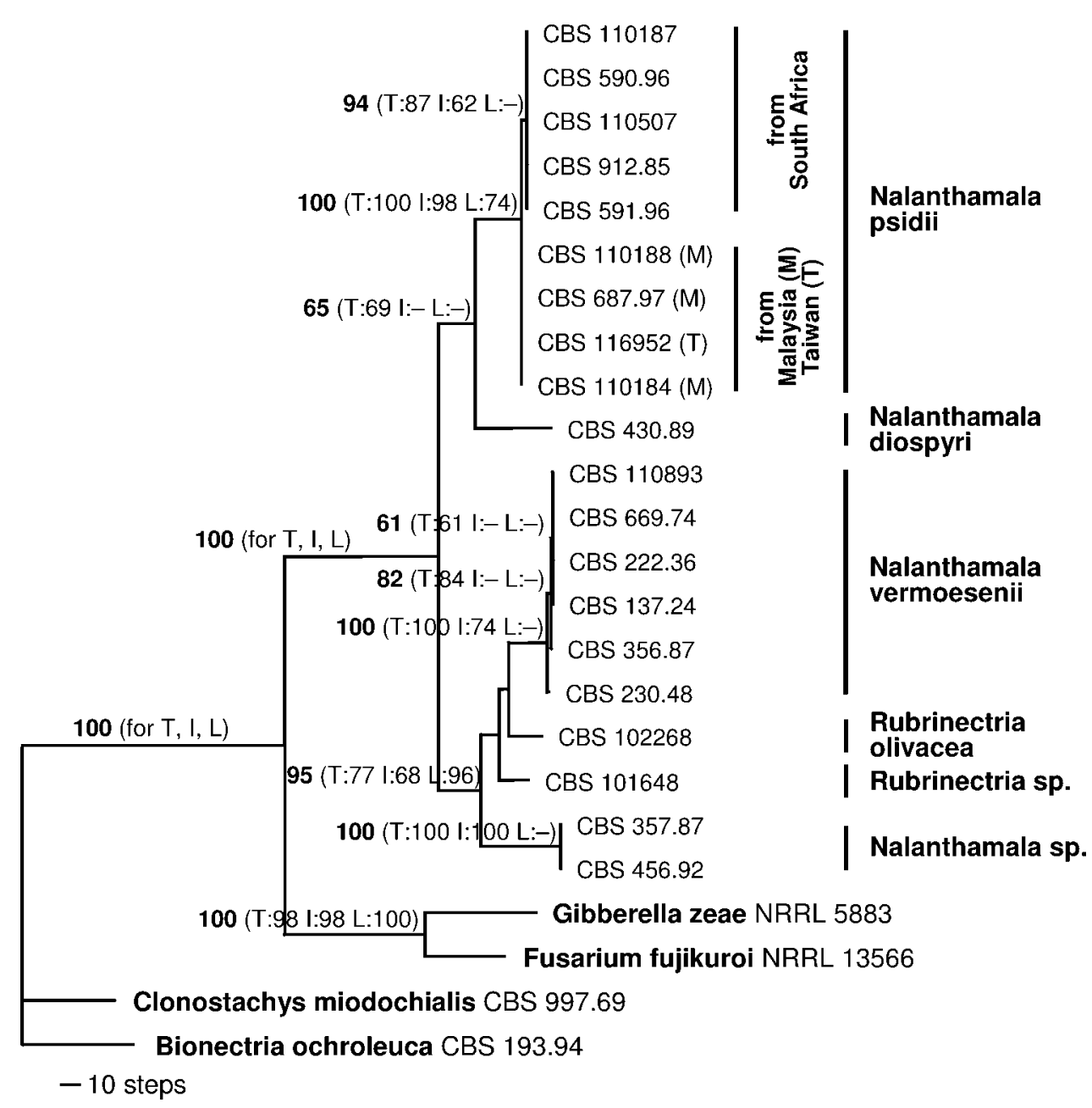

FIG. 2. One of three equally parsimonious phylograms inferred from the combined ITS1, 5.8S, ITS2 ribosomal DNA (ITS rDNA), partial LSU of the rDNA and partial $\beta$-tubulin dataset. Bootstrap intervals from 1000 replicates of the combined data are indicated above nodes, followed in brackets by intervals from 1000 replicates of the individual partitions $\beta$-tubulin (T), ITS rDNA (I) and LSU rDNA (L). The Nalanthamala sp., N. vermoesenii and the $N$. psidii clades are strongly supported (bootstraps $=100 \%$ ) as is the Rubrinectria/Nalanthamala clade (bootstrap $=100 \%$ ). Sister group relationship of $N$. diospyri and $N$. psidii is supported weakly (bootstrap $=65 \%$ ). The two ascospore isolates (Rubrinectria sp.) are more closely related to $N$. vermoesenii and Nalanthamala sp. $\mathrm{CI}=0.743 ; \mathrm{RI}=0.844$.

pansum was placed next to the root and outside of a moderately supported hypocrealean clade (bootstrap $=73 \%)$. Myrothecium inundatum, Peethambara sundara, Stachybotrys chartarum, S. echinata and S. bisbyi either formed an unresolved (encountered in five trees) or a monophyletic group (encountered in two trees, of which one is shown) (FIG. 1) at the base of the hypocrealean clade. The Bionectriaceae and the Hypocreaceae received moderate support (bootstrap $=71$ or $82 \%$, respectively). The Clavicipitaceae and the Nectriaceae formed monophyletic but not supported groups. Most of the included genera formed moderately to strongly supported clades. Ex-ascospore isolates of Rubrinectria specimens and conidial isolates of $N$. psidii, N. vermoesenii, Nalanthamala sp., isolated from palm, and N. diospyri form a moderate- ly supported monophyletic group (bootstrap = $77 \%$ ), which is placed among taxa of the Nectriaceae. The Rubrinectria clade appears closely related to Nectria cinnabarina and $N$. pseudotrichia, which belong to the type genus of the Nectriaceae. Other genera of the Nectriaceae, such as Mariannaea, Albonectria and the Gibberella fujikuroi species complex, which in part form conidia arranged in linear or imbricate chains, are related more distantly to Rubrinectria/ $\mathrm{Na}$ lanthamala. Gliocladium penicillioides Corda, type species of Gliocladium and anamorph of Sphaerostilbella aureonitens (Hypocreaceae) phylogenetically is unrelated to Rubrinectria, as are gliocladium-like taxa such as Roumegueriella rufula, Nectriopsis sporangiicola, and species of Bionectria (all Bionectriaceae). Taxa forming conidial chains such as Geosmithia species on 

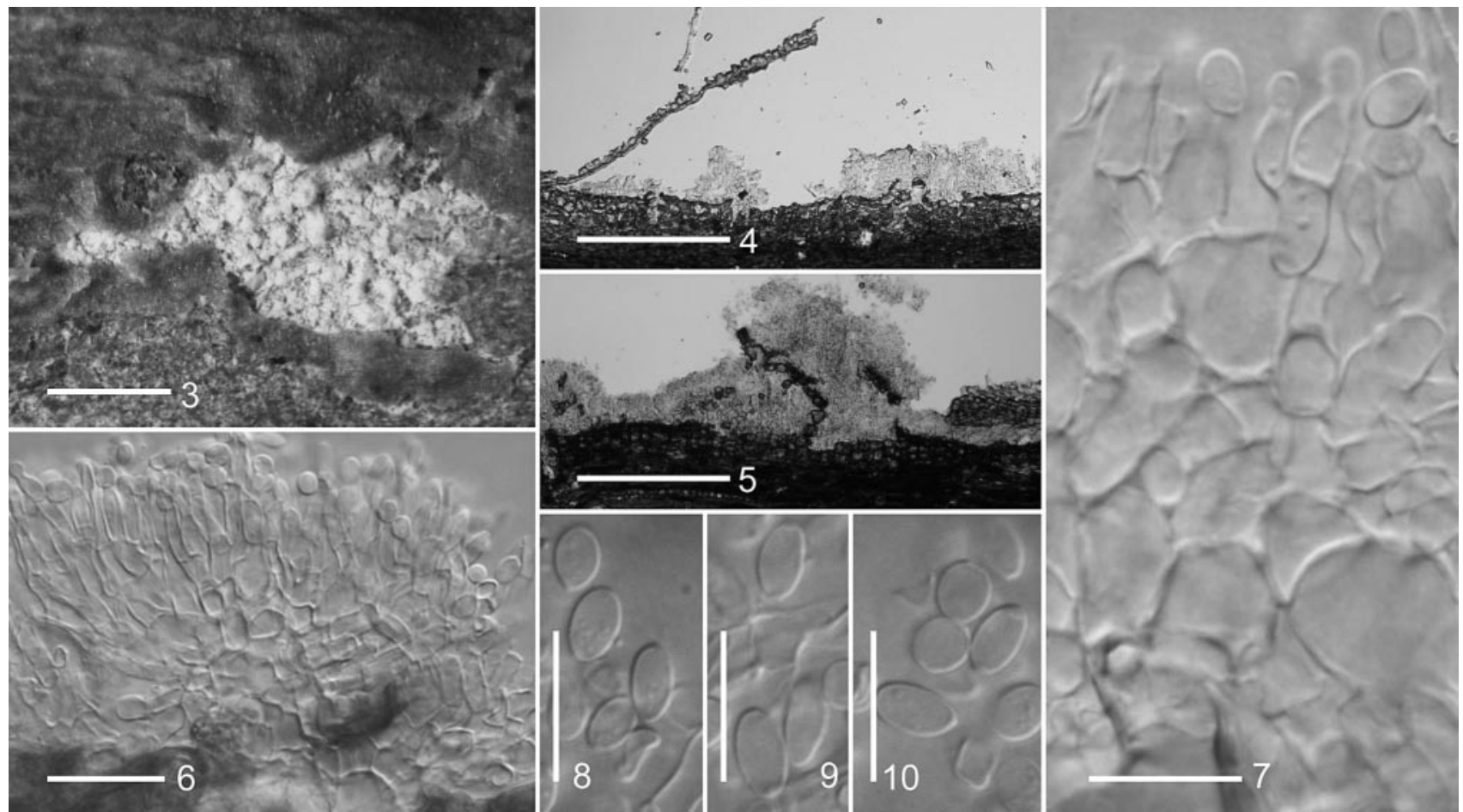

Figs. 3-10. Nalanthamala psidii on twig of diseased Psidium guajava. 3. Sporodochia pictured from above (whitish region) partly covered by outermost cortex of host. 4-7. Longitudinal sections through sporodochia. 8-10. Conidia. All from CBS, H-13961. Scale bars: $3=1 \mathrm{~mm} ; 4,5=100 \mu \mathrm{m} ; 6=20 \mu \mathrm{m} ; 7-10=10 \mu \mathrm{m}$.

penicillium-like conidiophores, Acremonium alternatum, the sporodochial "Nalanthamala" squamicola (all Bionectriaceae) also are unrelated phylogenetically to Rubrinectria. Stachybotrys chartarum, which forms slimy conidial heads, and S. echinata, which forms dry chains of conidia, are closely related and monophyletic.

Strains of N. psidii isolated from Malaysia and the single strain isolated from Taiwan had identical sequences. They differed from strains of N. psidii isolated from South Africa in two substitutions and one indel (a C2 instead of a C4 group) of the partial $\beta$ tubulin gene. Strains of $N$. vermoesenii contained five polymorphic intron sites, all of which were found in CBS 230.48, one of which was found in CBS 356.87. No variation was found within the partial $\beta$-tubulin gene of strains CBS 222.36, 110893, 669.74 and 137.24 ( N. vermoesenii), two strains of Nalanthamala sp. and two strains of $N$. diospyri, respectively. The ITS rDNA of $N$. vermoesenii strains was identical. The ITS rDNA of strains of N. psidii isolated from South Africa differed from strains isolated from Malaysia/ Taiwan in one substitution and one indel. Heuristic parsimony analyses of the combined partial LSU rDNA (525 bp alignment positions containing 63 PIC); ITS rDNA (505 bp alignment positions containing 103 PIC); and partial $\beta$-tubulin gene (662 bp alignment positions containing 207 PIC) resulted in three equally most parsimonious trees 740 steps in length with a CI of 0.743 and a RI of 0.844 , of which one is shown (FIG. 2). Monophyly of the Rubrinectria/Nalanthamala clade as well as the species clades of Nalanthamala sp., N. vermoesenii, and N. psidii were strongly supported (bootstrap $=100 \%$ ). Sister group relationship of $N$. psidii and $N$. diospyri was supported weakly (bootstrap $=65 \%$ ). Relatedness of the two ex-ascospore isolates of Rubrinectria, N. vermoesenii and Nalanthamala sp. was supported highly (bootstrap $=95 \%$ ); within this clade, the phylogenetic position of these species remained unresolved. The three trees and the bootstrap consensus tree suggested paraphyly of the strains from Asia (Malaysia and Taiwan) and South Africa, respectively. Partitioned parsimony and bootstrap analyses of the ITS rDNA (resulting in two equally parsimonious, 178steps-long trees having a CI of 0.781 and RI of 0.869) and the partial $\beta$-tubulin gene (resulting in ten equally parsimonious, 469-steps-long trees having a CI of 0.719 and RI of 0.819 ) also supported the $R u b$ rinectria/Nalanthamala, N. vermoesenii, $N$. psidii and Nalanthamala sp. clades (ITS rDNA: 100, 74, 98, $100 \%$ bootstrap support; $\beta$-tubulin: $100 \%$ for all taxa). Partitioned analysis of the LSU rDNA (resulting in four equally parsimonious, 90-steps-long trees having a CI of 0.822 and RI of 0.915 ) supported the 


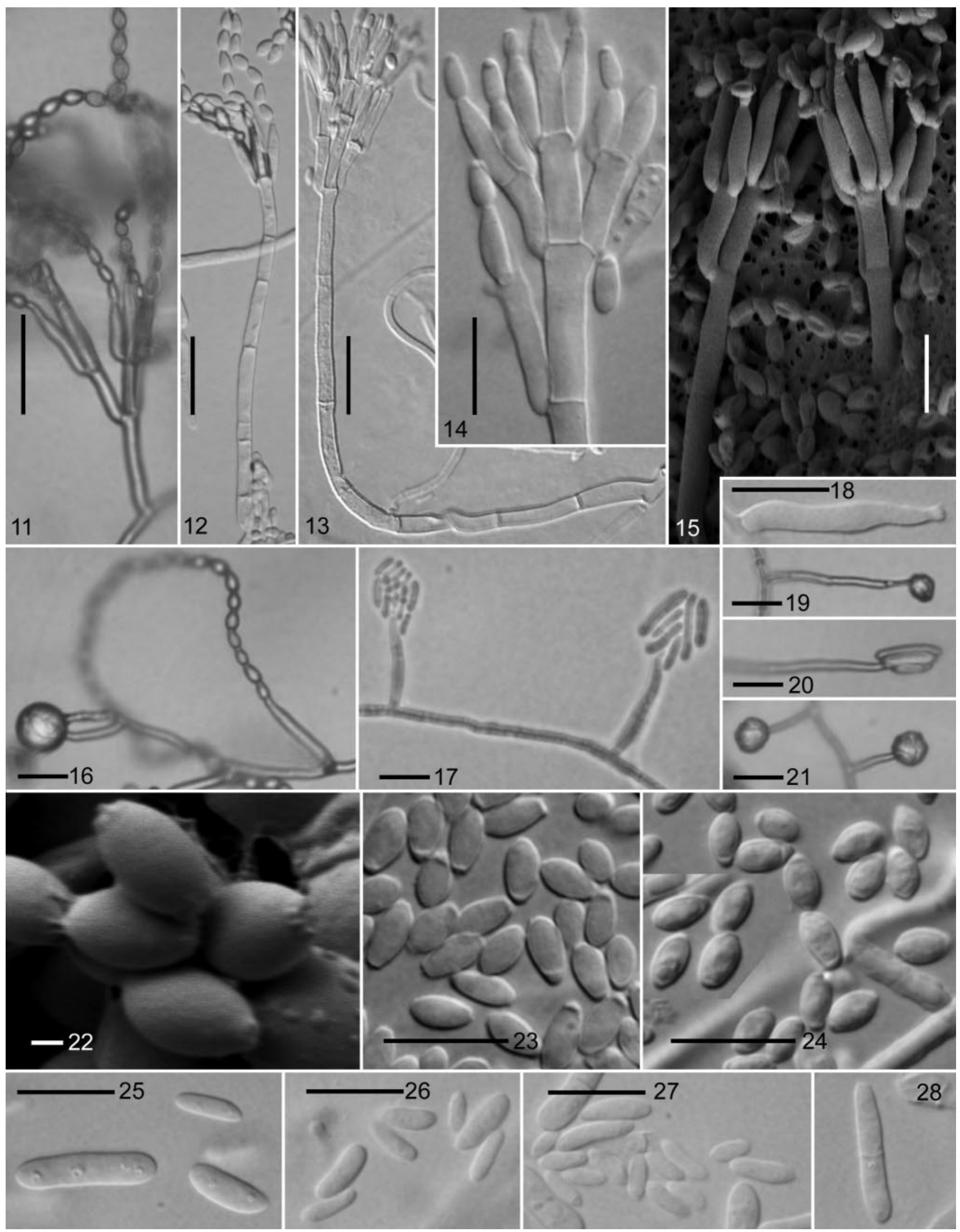

Figs. 11-28. Nalanthamala psidii in pure culture. 11-15. Penicillate conidiophores forming chains of ovoidal conidia. 16. Acremonium-like conidiophore forming chains of ovoidal conidia. 17-21. Acremonium-like conidiophores arising from aerial mycelium forming heads of ellipsoidal to fusiform, straight to slightly curved conidia. 22-24. Ovoidal conidia from linear 
Rubrinectria/Nalanthamala and the N. psidii clades (bootstrap $=100$ and $74 \%)$.

\section{TAXONOMY}

Nalanthamala Subramanian, J. Indian Bot. Soc. 35: 478. 1956.

TYPE SPECIES: N. madreeya Subramanian.

Sporulation on natural substratum by sporodochia or penicillate, stalked, mononematous or aggregated conidiophores. Sporodochia unpigmented, erumpent through outer cortex of substratum or formed in blisters below outermost host cortex, hemispherical or flat; cells of well-developed sporodochia angular to globose, forming a pseudoparenchymatous tissue (textura angularis), evenly thin-walled, hyaline. Phialides formed singly or in whorls on cylindrical cells that arise from pseudoparenchymatous tissue of sporodochia or in whorls on penicillately branched conidiophores, elongate, widest at the base or in the lower third, narrowing toward the apex or more or less cylindrical and narrowing below the apex. Conidia formed on sporodochia ovoidal, frequently with somewhat truncated ends, hyaline, 1-celled, smooth, held in dry chains.

Colonies yellowish, orange, brownish orange, or in light green, dark green, or olive-brown hues. Aerial mycelium sparsely to moderately developed, hyaline or greenish. Conidiophores in culture mostly dimorphic, penicillium-like or acremonium-like. Penicillium-like conidiophores short- or long-stalked, once or several times branched, with terminal whorls of phialides. Acremonium-like conidiophores of a single phialide or sparsely and sometimes irregularly branched, formed on submerged or aerial mycelium. Conidia generally dimorphic, either ovoidal or fusiform, cylindrical to allantoid, straight to slightly curved; ovoidal conidia mostly held in long chains, fusiform conidia held in heads. Conidial masses white or in pale yellowish, orange or salmon hues.

Teleomorph. Rubrinectria Rossman \& Samuels, Stud. Mycol. 42:164. 1999.

Descriptions. For the holomorph/teleomorph: Seaver (1910), Samuels (1973), Samuels and Brayford (1994), Rossman et al (1999); for the anamorph: Subramanian $(1956,1971)$.

Notes. The original description provided by Subramanian is expanded based on the observation of mononematous conidiophores on guava twigs and pure culture characters of species here included in Nalanthamala.

Nalanthamala madreeya Subramanian, J. Indian Bot. Soc. 35:478. 1956.

Diagnostic characters from original description. Sporodochia pseudoparenchymatous consisting of angular to globose, up to $28 \mu \mathrm{m}$ wide cells; phialides formed at the surface of sporodochia; conidia produced in linear, basipetal chains, elliptical-oval or lenticular, hyaline, 1-celled, smooth, mostly $7 \times 2.8 \mu \mathrm{m}$.

HOLOTYPE. INDIA. Madras, University Botany Laboratory campus. On dead stem, 3 Dec 1955, K. Ramakrishnan (Madras, University Botany Laboratory Madras, No. 1466).

Teleomorph. Unknown.

Habitat. On dead stem.

Distribution. India, only known from the type location.

Descriptions. Subramanian (1956, 1971).

Notes. Nalanthamala madreeya has not been described from pure culture. To our knowledge, the species has not been recollected. We could not locate the type specimen in the herbaria MUBL (now at the CAS in Botany, University of Madras, Guinday Campus, India) and IMI (CABI, Egham, Surrey, UK). The description provided by Subramanian (1956) allows the conclusion that Nalanthamala psidii is closely related to N. madreeya and that it is well accommodated in the genus Nalanthamala.

Nalanthamala psidii (Sawada \& Kurosawa) Schroers \& M.J. Wingf., comb. nov. Figs. 3-28.

$\equiv$ Myxosporium psidii Sawada \& Kurosawa, Rep. Taiwan Museum 83:59. 1926.

Sporulation on dead twigs as sporodochia and mononematous, penicillate conidiophores, covered by outermost cortex of host or exposed. Sporodochia unpigmented, up to $400 \mu \mathrm{m}$ diam, hemispherical, or flat, covering areas of up to $1 \mathrm{~cm}^{2}, 100-250 \mu \mathrm{m}$ high, white; cells of sporodochia angular to globose, 5-15 $\mu \mathrm{m}$ diam, forming a pseudoparenchymatous tissue (textura angularis), evenly thin-walled, hyaline, supporting phialides or phialides forming cylindrical cells. Conidiophores penicillate, solitary or formed in aggregates, mono- to quaterverticillate, forming

$\leftarrow$

chains formed by penicillate conidiophores. 25-28. Ellipsoidal to fusiform, typically 1-celled, rarely 1-septate conidia from simple, acremonium-like conidiophores. 15, 22 from $10 \mathrm{~d}$ old OA culture (SEM); all others from 7-14 d old SNA cultures. 11, 16, 17, 19, 20, 21 from CBS 912.85; 12, 13, 24, 26 from CBS 110507; 14, 18, 23, 25, 27, 28 from CBS 110188; 15, 22 from CBS 591.96. Scale bars: $11-13=20 \mu \mathrm{m} ; 14-21,23-27=10 \mu \mathrm{m} ; 22=1 \mu \mathrm{m}$; bar in 27 also applies to 28. 

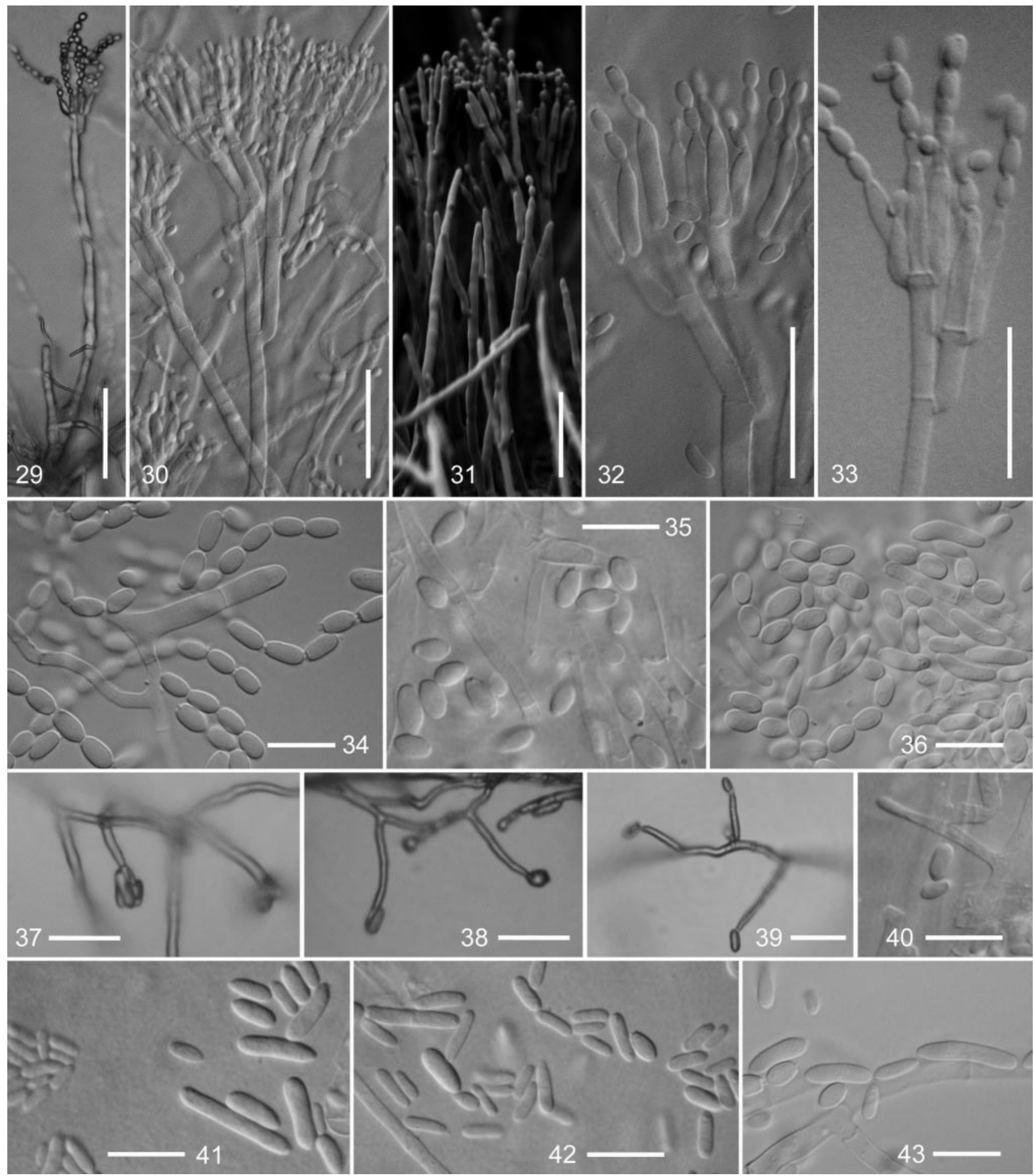

Figs. 29-43. Nalanthamala vermoesenii in pure culture. 29-33. Penicillate conidiophores forming chains of ovoidal conidia. 34, 35, partly 36. Ovoidal conidia from linear chains formed by penicillate conidiophores. 37-40. Acremonium-like conidiophores arising from aerial mycelium forming heads of ellipsoidal to fusiform conidia. 41-43, partly 36. Ellipsoidal to fusiform, straight to slightly curved conidia formed by simple, acremonium-like conidiophores. 31 from $4 \mathrm{~d}$ old OA culture (SEM), 37-39 from 4-7 d old OA cultures; all others from 10-14 d old OA cultures. 29, 30, 32, 34, 36, 37, 43 from CBS 110893; 31, 38 from 356.87; 33, 39 from CBS 669.74; 35, 40-42 from CBS 222.36. Scale bars: $29,31=30 \mu \mathrm{m}$; $30=50 \mu \mathrm{m}$; $32,33,37-39=20 \mu \mathrm{m} ; 34-36,40-43=10 \mu \mathrm{m}$. 


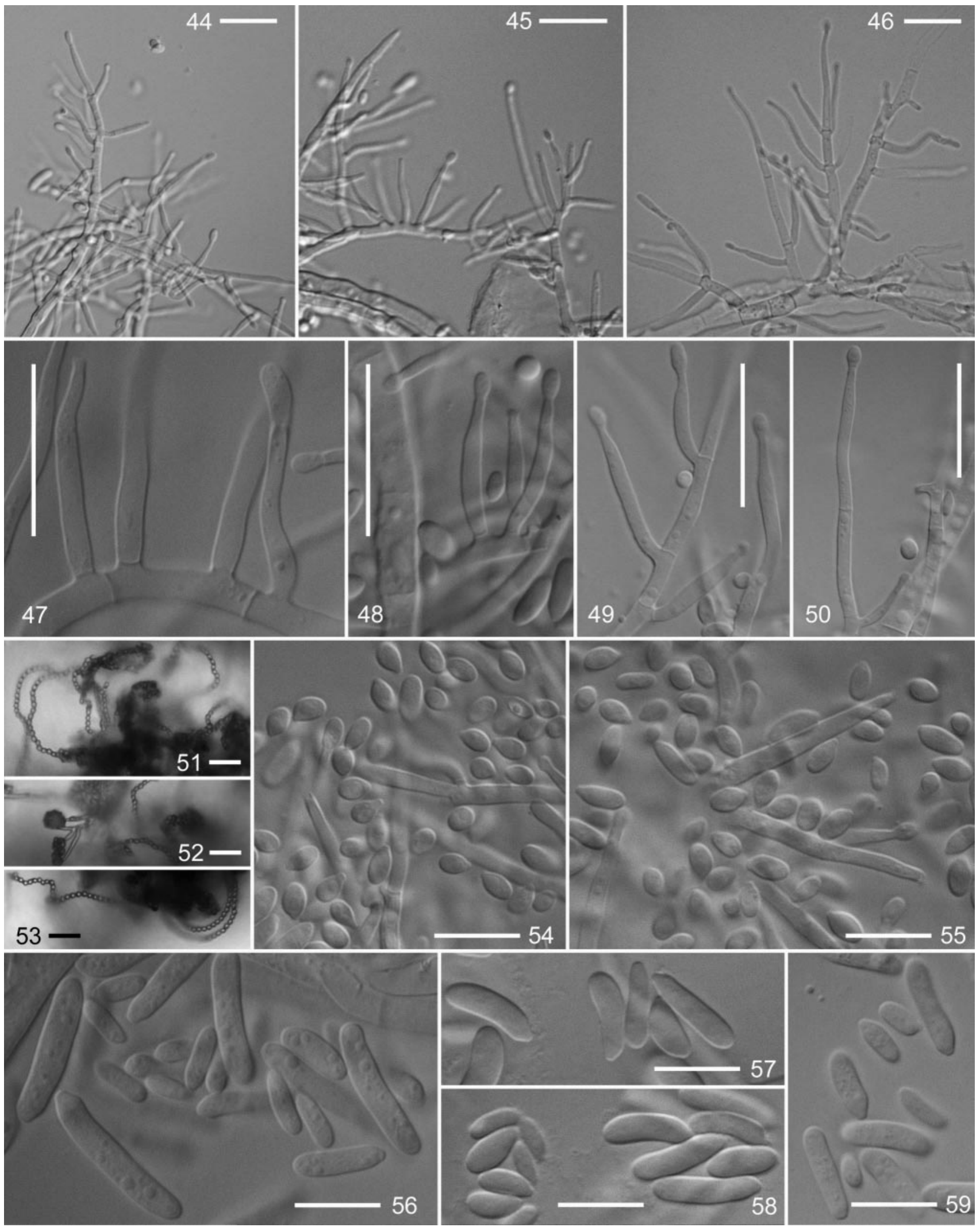

Figs. 44-59. Nalanthamala diospyri in pure culture. 44-50. Irregularly branched or simple, acremonium-like conidiophores. 51-53. Conidia arranged in chains. 54, 55. Ovoidal conidia with a truncated base and a rounded tip. 56-59. Ellipsoidal to fusiform, straight to slightly curved conidia with or without a visible, slightly laterally displaced hilum. All from $14 \mathrm{~d}$ old OA cultures of CBS 560.89. Scale bars: $44-53=20 \mu \mathrm{m}$; 54-59 $=10 \mu \mathrm{m}$. 
MyCOLOGIA

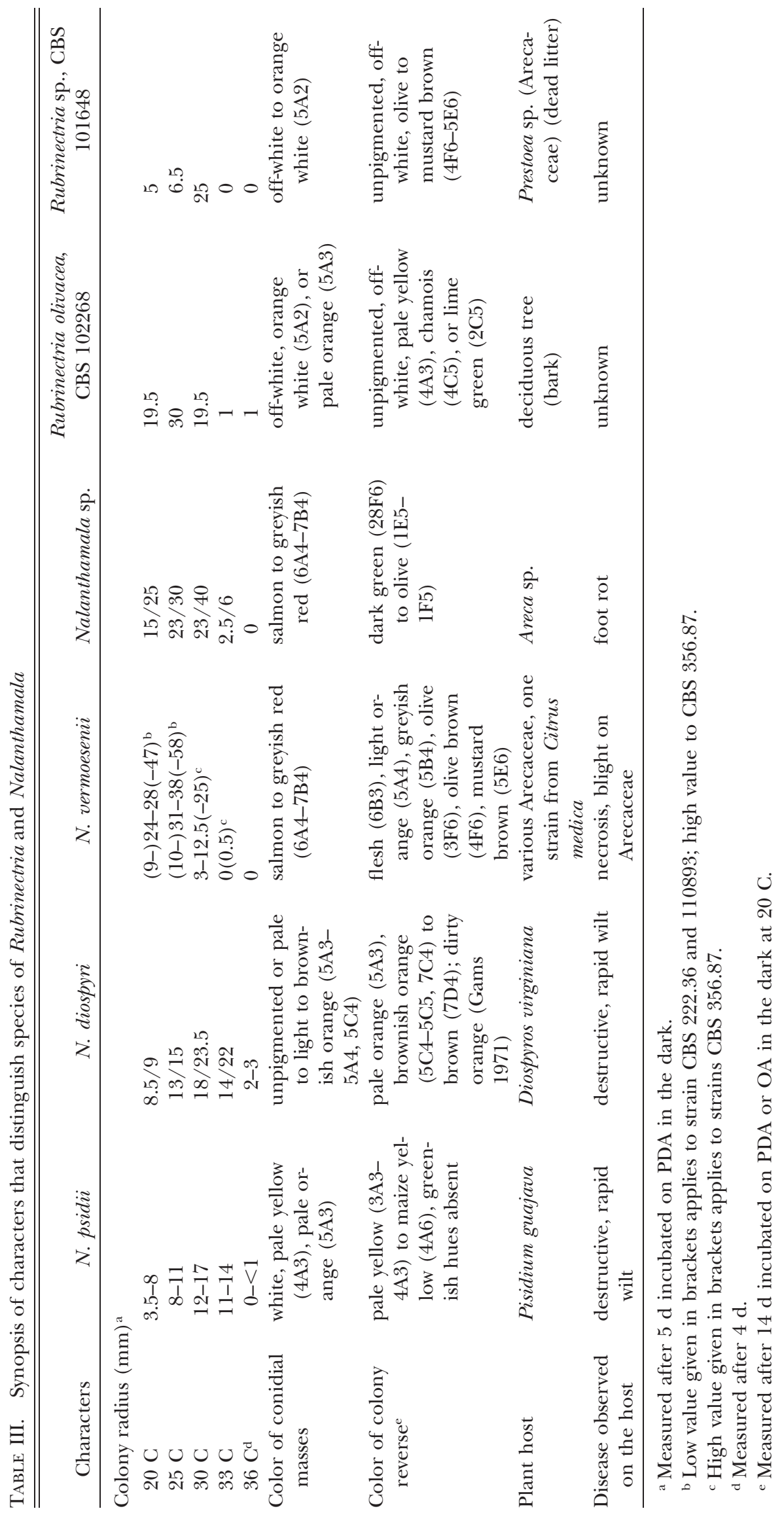


phialides in whorls. Phialides 5-12 $\mu \mathrm{m}$ long, 2-3.5 $\mu \mathrm{m}$ wide at base, 1-2 $\mu \mathrm{m}$ wide near apex. Conidia formed by sporodochia or penicillate conidiophores 1-celled, ovoidal, with somewhat truncated ends, held in dry chains, 4-5-6.7 × 2.5-3-3.5 $\mu \mathrm{m}(\mathrm{n}=79)$.

Colonies reaching a radius of $8-11 \mathrm{~mm}$ at $25 \mathrm{C}$ when incubated $5 \mathrm{~d}$ on PDA in the dark. Reverse on $\mathrm{OA}$ and PDA pale yellow (3A2-3A3) after $14 \mathrm{~d}$ incubation in the dark, later or after incubation under near-UV, becoming light yellow (4A5), maize yellow (4A7), light orange (5A5) or chrome yellow (5A8), particularly in the colony center; greenish hues absent; on SNA unpigmented. Colony surface on OA and PDA cottony, in pale yellowish hues or appearing white due to moderately developed aerial mycelium and conidial masses. Conidiophores dimorphic, penicillate and acremonium-like. Penicillate conidiophores arising from hyphae growing near the agar surface or from aerial hyphae; stipe consisting of one or several cells, 20-200 $\mu \mathrm{m}$ long or longer, up to 7 $\mu \mathrm{m}$ wide at the base; penicillus consisting of a single whorl of phialides (monoverticillate) or several times branched (bi- to quaterverticillate), 15-50 $\mu \mathrm{m}$ high, typically adpressed or with slightly diverging primary branches; metulae $6-14 \times 2-3 \mu \mathrm{m}(\mathrm{n}=20)$; phialides in whorls of usually 4, narrowly bottle-shaped, widest in the lower third and slightly narrowing toward the tip, or more or less cylindrical and narrowing below the apex, (7.5-) 11.5-13-15(-20) $\mu \mathrm{m}$ long, 1.5-3.2 $\mu \mathrm{m}$ wide at base, $2.1-3.1 \mu \mathrm{m}$ wide in the lower third, and 1-2 $\mu \mathrm{m}$ wide at the tip $(\mathrm{n}=99)$. Acremonium-like conidiophores formed submerged or by aerial hyphae, unbranched; phialides cylindrical or slightly tapering toward the tip, frequently somewhat bent, 10-30 $\mu \mathrm{m}$ long, 2-3 $\mu \mathrm{m}$ wide at base, and 1.2-1.4 $\mu \mathrm{m}$ wide at tip. Conidia dimorphic: on penicillate conidiophores (rarely also on simple or sparsely branched conidiophores) ovoidal, typically with somewhat truncated ends, (3.3-) 4.5-4.8-5.1(-6.5) $\times$ (1.9-) 2.4-2.6-2.7(-3.4) $\mu \mathrm{m}(\mathrm{n}=450)$, 1-celled, typically held in long, dry, persisting chains, slightly hydrophobic, in masses white or pale yellow to pale orange (4A3-5A3); on acremonium-like conidiophores ellipsoidal, cylindrical, or fusiform, with obtuse ends, or with an obtuse tip and a visible, slightly laterally displaced hilum, (3.5-)6-8.5-11(-20) × (1.2-)1.7$2.5-2.8(-5) \mu \mathrm{m}(\mathrm{n}=150)$, typically 1 -celled, rarely 2-celled because of a transverse septum, held in liquid drops at the tip of the phialides. Chlamydospores not observed.

HOLOTYPE. TAIWAN. Figure in Rep. Taiwan Museum 83:50. 1926. SYNTYPES. Chang-hua Co., on wood of Psidium guajava, 10 Aug 1923, E. Kurosawa. Chia-yi Co., on wood of Psidium sp., 8 Sep 1923, K. Sawada (both herb. Universitatis Taiwanensis). EPI-
TYPE of Myxosporium psidii, designated herewith: Dried culture of CBS 116952 (BPI), filed together with BPI 863661 from which CBS 116952 was isolated. TAIWAN: Tainan Co., Ho-pi, on wood of Psidium guajava, 7 Sep 2004, coll. by Y.-F. Yen, isol. by Yuming Ju (BPI 863661, AR 4095; CBS 116952).

Teleomorph. Unknown.

Habitat. Decaying twigs or trunks of Psidium guajava trees in guava plantations, causing a destructive wilt disease.

Distribution. Guava orchards in Malaysia, South Africa and Taiwan, possibly restricted to subtropical or tropical regions.

Description. Kurosawa (1926) (in Japanese), Leu et al (1979).

Additional strains and specimens examined. All from Psidium guajava. MALAYSIA. M. Schoeman (CBS 110182, 110183, 110184). Beaumont cultivar, H.C. Tuck (CBS 687.97). SOUTH AFRICA. LIMPOPO: Levubu. M. Schoeman (CMW 8608). MPUMALANGA: Nelspruit. M. Schoeman (CBS 110185, 110186, 110187). N. Grech (CBS 912.85). M.J. Wingfield (CBS 590.96, 591.96). Twigs of dead Psidium guajava trees that were removed from the plantation and kept drying for several months, Mar 2002, B.Q. Manicom (herb. CBS, H-13961; CBS 110507).

Notes. Two syntypes of $M$. psidii are deposited at the herbarium of the Taiwan National University of which the specimen from Chia-yi County collected by E. Kurosawa is in good condition. Structures illustrated here from the natural substratum of a specimen from South Africa (FIGS. 3-10) match those encountered on both syntypes and in the illustration provided by Kurosawa (1926). On their natural substrata, Nalanthamala psidii (FIGs. 3-10) and N. madreeya (Subramanian 1956, Figs. 1-8) form morphologically similar conidia, conidial chains and sporodochia. Conidia of chains of $N$. psidii mostly are shorter than $6 \mu \mathrm{m}$, while those of $N$. madreeya were described as mostly $7 \mu \mathrm{m}$ long (Subramanian 1956). In culture, N. psidii typically forms penicillate (FIGS. 11-15) and acremonium-like (FIGS. 16-21) conidiophores simultaneously. Most of the strains studied, however, showed tendencies to form sectors, in which acremonium-like conidiophores dominated and penicillate conidiophores with conidial chains were sparsely formed or inconspicuous. No morphological discontinuity was observed by which strains from South Africa and Asia (Malaysia and Taiwan) might be distinguished. Strains from South Africa and Malaysia showed similar disease symptoms. Growth rates for $N$. psidii strains varied somewhat at $20 \mathrm{C}$ but were less variable at 25, 30 and $33 \mathrm{C}$. Pale yellowish to pale orange colony pigments on $\mathrm{OA}$ and PDA and relatively well growing colonies at $33 \mathrm{C}$ distinguish $N$. psidii from mostly greenish pigmented Nalanthamala 
taxa, frequently associated with palm hosts and generally not or hardly growing at $33 \mathrm{C}$ (TABLE III).

\section{Nalanthamala vermoesenii (Biourge) Schroers, comb. nov. Figs. 29-43. \\ $\equiv$ Penicillium vermoesenii Biourge, La Cellule 33:230. 1923. \\ $\equiv$ Gliocladium vermoesenii (Biourge) Thom, The Penicil- lia, p. 502. 1930.}

Colonies typically reaching a radius of $31-38 \mathrm{~mm}$ at $25 \mathrm{C}$ when incubated $5 \mathrm{~d}$ on PDA in the dark. Reverse on OA and PDA flesh (6B3), light orange (5A4), grayish orange $(5 \mathrm{~B} 4)$, yellowish green (3C3-3C7, 30A8), olive (3F6), olive brown (4F6), or mustard brown (5E6); on SNA unpigmented or with a faint of green. Colony surface on OA and PDA dusty to fine powdery, salmon to grayish red (6A4-7B4) due to occurrence and color of conidial masses; aerial mycelium sparsely developed. Conidiophores dimorphic, penicillate and acremonium-like. Penicillate conidiophores arising from agar surface or hyphae growing near the agar, in young colonies also from the weakly produced aerial mycelium; stipe consisting of one or several cells, up to $200 \mu \mathrm{m}$ long or longer, up to 7 $\mu \mathrm{m}$ wide at the base; penicillus monoverticillate to quaterverticillate, 15-70 $\mu \mathrm{m}$ high, typically adpressed or with slightly diverging primary branches; metulae $7.5-16.5 \times 2.5-3.5 \mu \mathrm{m}(\mathrm{n}=20)$; phialides narrowly bottle-shaped, widest in the lower third and slightly narrowing toward the tip, or more or less cylindrical and narrowing below the apex, (8.5-)11-12.514(-19) $\mu \mathrm{m}$ long, 2-3 $\mu \mathrm{m}$ wide at base, 2.5-3 $\mu \mathrm{m}$ wide in the lower third, and $1-1.5 \mu \mathrm{m}$ wide at the tip $(\mathrm{n}=42)$. Acremonium-like conidiophores submerged or formed by aerial hyphae, unbranched, sometimes sparsely branched; phialides cylindrical or slightly tapering toward the tip, sometimes somewhat bent, 10-30 $\mu \mathrm{m}$ long, 2-2.5 $\mu \mathrm{m}$ wide at base, 1-1.5 $\mu \mathrm{m}$ wide at tip $(\mathrm{n}=10)$; submerged conidiogenous cells also shorter, up to $5 \mu \mathrm{m}$ long. Conidia dimorphic: on penicillate conidiophores ovoidal, typically with somewhat truncated ends, (3-) 4-4.5-5(-7.5) $\times$ (1.5-) 2.5-2.5-3(-4.5) $\mu \mathrm{m}(\mathrm{n}=162)$, 1-celled, typically held in long, dry, persisting chains, somewhat hydrophobic, in masses appearing salmon (6A4); on acremonium-like conidiophores ellipsoidal, cylindrical, or fusiform, straight or slightly curved, with obtuse ends, or with an obtuse tip and a visible, slightly laterally displaced hilum, (4-)5-7-8(-17) $\times(1.5-)$ 1.5-2-3(-4.5) $\mu \mathrm{m}(\mathrm{n}=89)$, 1-celled, held in liquid drops at the tip of phialides. Chlamydospores not observed.

NEOTYPE for Penicillium vermoesenii, designated herewith: Location unknown. From Areca sp. Dried
OA culture of CBS 110893 (= MUCL 9504, Biourge 415, ex-type strain of Penicillium vermoesenii) (herbarium CBS, H-13962).

Teleomorph. Unknown.

Habitat. Various Arecaceae, causing necrosis and blight; also reported once from Citrus medica.

Distribution. Particularly known from warm temperate, Mediterranean, or (sub) tropical climates; also known from hosts kept in glasshouses of other climatic regions.

Description. Biourge (1923).

Strains examined. Location unknown, from palm, A. van Luijk, No. 7 (CBS 137.24, MUCL 7994, Biourge 416). USA. CALIFORNIA: South Pasadena, from Phoenix canariensis Hort. ex Chabaud, pathogenic to Syagrus romanzoffiana (Cham.) Glassm., Phoenix canariensis, Washingtonia filifera H. Wendl., Nov 1931, D.E. Bliss (CBS 222.36). AUSTRALIA. VICTORIA: Burnley Gardens, leaf of palm, I. Pascoe (CBS 356.87, FRR 3073). CZECH REPUBLIC. SOUTHERN MORAVIA: Palm house at Lednice village, decayed basal part of petiole of Latania sp., Dec 1971, V. Holubová-Jechová (CBS 669.74, IMI 160990). SPAIN. From Citrus medica (CBS 230.48, ATCC 10522, DSM 3709, IMI 040231, MUCL 7584, NRRL 1752).

Notes. Nalanthamala vermoesenii and N. psidii differ in colony growth rates (TABLE III). Nalanthamala psidii has a temperature optimum of around $30 \mathrm{C}$ and continues to grow at $33 \mathrm{C}$, while $N$. vermoesenii grows most rapidly at approximately $25 \mathrm{C}$ and does not grow at 33 C. Both species differ in the pigmentation of the conidial chains or masses, in the pigmentation of colonies on OA and PDA, and in their plant hosts (TABLES II, III).

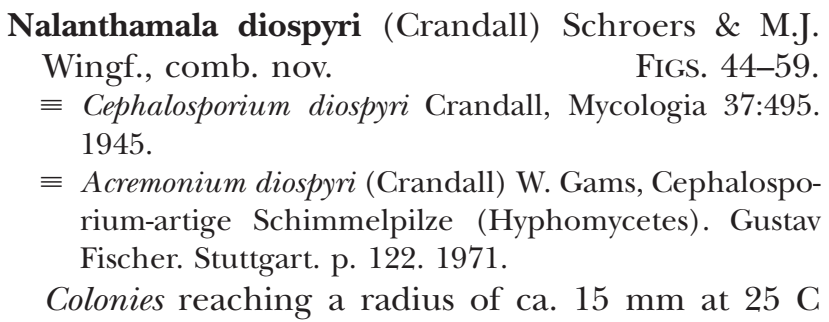
when incubated $5 \mathrm{~d}$ on PDA in the dark. Reverse on $\mathrm{OA}$ and PDA pale orange (5A3), brownish orange (5C4-5C5, 7C4) to brown (7D4). Colony surface on $\mathrm{OA}$ and PDA dusty and white due to sporulation from sparsely formed aerial mycelium or slimy and brownish orange (5C4-5C5, 7C4) due to sporulation on agar surface. Conidiophores irregularly branched or acremonium-like as single phialides; phialides mostly cylindrical, narrowing slightly in the upper third, somewhat bent, (12.5-)16-21-25(-35.5) $\mu \mathrm{m}$ long, $1.5-3 \mu \mathrm{m}$ wide at base, $1-2$ wide at tip $(\mathrm{n}=$ 30). Conidia either obovate, with an obtuse tip and a truncated base, 1-celled, formed in chains or heads, $(3.5-) 4-4.5-4.5(-6) \times(2-) 2.5-2.5-2.5(-4) \mu \mathrm{m}(\mathrm{n}=$ 
95) or ellipsoidal, cylindrical, or fusiform, straight or slightly curved, with obtuse ends or with an obtuse tip and a visible, slightly laterally displaced hilum, 1celled, formed in heads, (4.5-)8-10.5-12(-20) $\times$ (2-)2.5-3-3.5(-4.5) $\mu \mathrm{m}(\mathrm{n}=107)$. Chlamydospores not observed.

Teleomorph. Unknown.

Habitat. Bark of Diospyros virginiana, American persimmon, causing a destructive wilt.

Distribution. Southeastern USA.

Descriptions. Crandall (1945), Durrell (1963), Gams (1971).

Strains examined. USA. TENNESSEE: Readyville, from wood of Diospyros virginiana, B.C. Crandall (CBS $560.89=$ CBS 131.51, ATCC 9066, DSM 2939, IFO 6118, MUCL 9732). MISSISSIPPI: From Diospyros virginiana, B.C. Crandall BC-1 (CBS $430.89=$ ATCC 22202).

Notes. In young colonies, Nalanthamala diospyri forms conidial chains only sparsely but more abundantly in colonies older than $14 \mathrm{~d}$, particularly on OA and PDA. The lack of penicillate conidiophores, shape of conidia that are arranged in chains, colony pigmentation, and host spectrum distinguish it from other Nalanthamala species (TABLE III). Chain formation of the obovate conidia and the two types of conidia encountered links $N$. diospyri morphologically to the other Nalanthamala species.

Nalanthamala sp.

Habitat. On diseased Areca sp.

Distribution. Netherlands.

Strains examined. NETHERLANDS. Maasdijk, greenhouse, from leaf of Areca sp. J.W. Veenbaas-Rijks (CBS 456.92). Naaldwijk, from Areca catechu, causing foot rot (CBS 357.87, PD 86/1179).

Notes. Two conidial isolates of this Nalanthamala species are available. They are similar to $N$. vermoesenii in micro- and macromorphological features and both species inhabit Arecaceae (TABLES II, III). $\mathrm{Na}$ lanthamala sp. is distinguished weakly from $N$. vermoesenii by faster colony growth rates, particularly at $30 \mathrm{C}$, and by darker, greenish colony pigmentation (TABLE III).

Rubrinectria olivacea (Seaver) Rossman \& Samuels, Stud. Mycol. 42:164. 1999.

= Macbridella olivacea Seaver, Mycologia 2:178. 1910.

Synonymy. Samuels (1973), Rossman et al (1999).

HOLOTYPE (NY). MEXICO. Motzorongo, near Córdoba, in moist forest, on stem of unidentified palm, 15 Jan 1910, Murrill E Murrill 911.

Anamorph. Nalanthamala sp.

Habitat. Known from palm and bark.

Distribution. Mexico, Costa Rica, ?Philippines, possibly restricted to tropical regions.
Additional specimens examined. COSTA RICA. Limon, Puerto Viejo, Refugio Nacional Mendoza-Manzanilla, 0-50 m elevation, on bark, 8 Jul 1999, G.J. Samuels 8532, P. Chaverri, S. Salas et al (BPI 746597; culture G.J.S. 99-72/ 99-178, CBS 102268). PHILIPPINES. Luzon, Mount Maquiling, on bark, 23-28 Feb 1912, P.W. Graff, Lloyd 11408 (BPI 801936).

Descriptions. Seaver (1910), Samuels (1973), Samuels and Brayford (1994), Rossman et al (1999).

Notes. The two examined specimens form perithecia on well-developed erumpent stromata. The same kind of stroma was described for the type of $R$. olivacea (illustrated by Samuels and Brayford 1994). However, they originate from bark of deciduous trees, while the type specimen was described from a palm host. Strain CBS 102268 is characterized mainly by off-white, pale yellow or chamois colony pigments and white conidial masses, however, in older OA and PDA colonies yellowish green or lime green (2C5) pigments also developed, similar to those formed by N. vermoesenii and Nalanthamala sp.

Rubrinectria sp.

Anamorph. Nalanthamala sp.

Habitat. Known from dead parts of palm.

Distribution. USA, Puerto Rico.

Specimen examined. USA. PUERTO RICO: Caribbean National Forest, Luquillo Mountains, Big Tree Trail, on litter of Prestoea sp. (Arecaceae), 19 Jun 1998, W. Gams, H.-J. Schroers 278 (CBS 101648).

Notes. This Rubrinectria sp. is characterized by small, poorly developed, erumpent perithecial stromata and differs by that from the well-developed stromata found in $R$. olivacea. Additional specimens would need to be examined to determine whether the stromatal morphology has significance in distinguishing it from $R$. olivacea. Rubrinectria sp. (CBS 101648) forms perithecia homothallically in cultures. Perithecia are initially dull orange to dull red but become greenish-black because of olivaceous granules on the perithecial wall. Ascospores are brownish, coarsely striate and appear in olivaceous-black cirri. The pigmentation of the perithecia as well as the ornamentation and pigmentation of the ascospores are diagnostic of the genus (Seaver 1910, Samuels 1973, Samuels and Brayford 1994, Rossman et al 1999).

\section{DISCUSSION}

Nalanthamala is the appropriate genus for the guava pathogen.-Nalanthamala psidii was described originally in Myxosporium (Kurosawa 1926), but this genus was rejected by von Höhnel (1915) and regarded as nomen nudum by Sutton (1977) because its type species, $M$. croceum, is based on a mixture of different 
fungi. Similarities of conidiomata, conidia and conidial chains formed by Nalanthamala madreeya and $N$. psidii on their natural substrata led us to conclude that both species are congeneric. Similar conidiomata are formed also by Nectria cinnabarina (Seifert 1985), however, conidia of $N$. cinnabarina are formed in slimy masses but not in chains. Sporodochia of Dendrodochium Bonorden and other sporodochial genera listed as synonyms under Clonostachys (Schroers 2001) have a hyphal subhymenium and dry, linear chains of conidia have been described for none of these genera. Volutella Fr. and Myrothecium Tode are characterized by setae (Domsch et al 1980), which were not described for N. madreeya nor observed in N. psidii. Nalanthamala madreeya was not described from pure cultures (Subramanian 1956) and could not be compared with $N$. psidii in vitro.

Rubrinectria, teleomorph of Nalanthamala, belongs to the Nectriaceae.-Based on LSU rDNA sequence analyses, $N$. psidii, $N$. vermoesenii, $N$. diospyri and two exascospore isolates of Rubrinectria form a monophyletic group among taxa of the Nectriaceae (Hypocreales), which is particularly rich in plant-pathogenic or plant-invading taxa (Gerlach and Nirenberg 1982, Rossman et al 1999). One of the ex-ascospore isolates was identified as $R$. olivacea based on morphological characters of the teleomorph. This phylogeny supports classification of Rubrinectria in the Nectriaceae based on morphological characters (Rossman et al 1999) and links Rubrinectria with the anamorphic genus Nalanthamala. The connection is supported by the similar dimorphism of conidiophores and conidia in N. vermoesenii, $N$. psidii, Nalanthamala sp., and the ex-ascospore isolates of Rubrinectria.

Classification of Rubrinectria/Nalanthamala in the Nectriaceae is in agreement with results of chemotaxonomic studies that suggested close relationship of $N$. vermoesenii with Fusarium sp. and Nectria cinnabarina rather than species of Penicillium and Clonostachys (cited as Gliocladium roseum, Nectria sp. or Sesquicillium sp.) (Ahrazem et al 1999, 2001).

Nalanthamala and phenotypically similar taxa.-Rubrinectria/Nalanthamala is unrelated to eurotialean or hypocrealean taxa characterized by penicillate conidiophores either forming conidial chains or heads (FIG. 1). "Nalanthamala" squamicola (Gams 1975) the only other species ever classified in Nalantham$a l a$, is excluded from the Nalanthamala/Rubrinectria clade, clustering instead with members of the Bionectriaceae. It forms sporodochia abundantly in pure culture, while well-developed sporodochia have not been observed in cultures of taxa classified here in Nalanthamala.

In $N$. psidii, stability of conidial chains is achieved apparently by wall material connecting subterminal parts of adjacent conidia (FIG. 22), while, in Penicillium, chain stability is achieved by connectives that attach central terminal points of two adjacent conidial apices (Gams 1978, Cole and Samson 1979). In other genera of the Hypocreales forming conidial chains, conidia also can be connected to each other through an amorphous mucous matrix (Gams 1978).

The polyphyletic distribution of taxa with penicillate conidiophores forming either linear chains or mucous heads of conidia has been discussed for several cases (Berbee et al 1995, Ogawa et al 1997, Rehner and Samuels 1994) and might suggest that overall morphological characters of these anamorphs are inconclusive for classification schemes. Our morphological analysis, however, indicates that a more sound generic delimitation can be achieved when various characters from culture, in addition to those from the natural substratum, are considered jointly. The close relationship of Stachybotrys chartarum, which forms slimy masses of conidia, and S. echinata, which forms linear chains of conidia, previously postulated based on morphological observations (Smith 1962) and confirmed by sequence data (Haugland et al 2001, this paper) is consistent with this view.

Distinction and phylogeny of Nalanthamala species.Nalanthamala diospyri is characterized by ovoidal conidia showing truncation only at the base, while truncation is shown at both conidial ends in other Nalanthamala species, and by irregularly branched conidiophores. Penicillate conidiophores were not observed. Absence of penicillate conidiophores also was observed sometimes in colony sectors of $N$. psidii, and the lack of this feature could be explained by degeneration in vitro. Conidial chains and the two kinds of conidia formed by $N$. diospyri also were described in earlier studies (Durrell 1963, Gams 1971). They support classification of $N$. diospyri in Nalanthamala. All other Nalanthamala species showed similar conidiophores and conidia. Nalanthamala vermoesenii, N. psidii and N. diospyri are distinguished from each other by macroscopical characters such as pigmentation of colonies and conidial masses and growth rates (TABLE III). Nalanthamala vermoesenii, Nalanthamala sp. and Rubrinectria sp. form a supported monophyletic group, of which $N$. diospyri and N. psidii are sister taxa (FIG. 2). Most strains of this monophyletic group are pathogenic to or originating from palm hosts and are characterized by greenish colony pigments ranging from yellowish green to dark olive as well as salmon or white conidial masses. Nalanthamala vermoesenii strain CBS 230.48 and $R$. olivacea strain CBS 102268 were isolated from Citrus medica or bark of a deciduous tree, respectively, how- 
ever, the type of $R$. olivacea, which could not be included in the molecular analysis, originated from palm.

Infraspecific variation within $\mathrm{N}$. psidii and N. vermoesenii.-Two polymorphic sites in the ITS rDNA and three in the partial $\beta$-tubulin gene consistently distinguished morphologically identical N. psidii strains from South Africa and Malaysia/Taiwan. DNA sequence data therefore support occurrence of distinct lineages within $N$. psidii. Because monophyly of the two lineages was not supported by sequence data and paraphyly was seen instead (FIG. 2), subspecific phylogenetic taxa were not distinguished.

Five strains of $N$. vermoesenii including the ex-type strain (CBS 110893) originate from palm species on three continents (TABLE II). With the exception of one nucleotide change in the partial $\beta$-tubulin gene of strain CBS 356.87, sequences thus far examined are identical for these strains. Molecular data, therefore, support earlier assumptions concerning distribution and host specificity of $N$. vermoesenii (Aragaki et al 1991, Farr et al 1989, Raper and Thom 1949). The strains are homogeneous in overall morphological characters but show variable growth rates at 20, 25 and 30 C. Slow growth was observed in two strains (CBS 222.36 and CBS 110893) that have been maintained in culture collections for many years, while more recently isolated strains grew more rapidly in culture. Relatedness of CBS 230.48 to the core group of $N$. vermoesenii is supported by sequence data (bootstrap value for the species clade of $N$. vermoesenii $=100 \%$ ) (FIG. 2) and by overall micro- and macroscopical characters. It differed from the core group of $N$. vermoesenii in several nucleotides of the partial $\beta$-tubulin gene sequences and in its occurrence on Citrus medica. No additional data regarding its ecology and pathogenicity on Citrus medica are available.

Pathogenicity and ecology.-Crandall and Baker (1950) characterized the persimmon wilt caused by $N$. diospyri as abrupt, rapidly spreading throughout the tree and causing discoloration of leaves at the tops of trees, followed by general wilting, rapid defoliation and death within a few months; conidia of $N$. diospyri form in orange masses below the bark resulting in red erumpent blisters. These symptoms are comparable to those caused by $N$. psidii on Psidium guajava (Leu et al 1979, Schoeman et al 1997).

Wounds are required for infection of persimmon trees by $N$. diospyri (Crandall and Baker 1950) and of palms by $N$. vermoesenii (López-Llorca and Orts 1994). Crandall and Baker (1950) demonstrated that $N$. diospyri infects persimmon trees by airborne conidia. Conidia of N. psidii held in long, dry chains are well adapted for wind dispersal and, like $N$. dios- pyri and $N$. vermoesenii, infect guava trees through naturally and artificially inflicted wounds (Leu et al 1979).

\section{ACKNOWLEDGMENTS}

We thank Amy Rossman, curator of the herbarium BPI, for the loan of specimens and especially for suggesting the correct basionym of the guava pathogen. We thank Gary Samuels (USDA, Beltsville) and Pierre Evrard (MUCL, Belgium) for providing strains; Barry Manicom for providing a specimen of the guava pathogen; Richard Summerbell (CBS), Walter Gams (CBS), Gary Samuels and two anonymous reviewers for critical comments on earlier drafts of this manuscript; Yu-Ming Ju (Institute of Botany, Academia Sinica, Taiwan) for providing an isolate of $N$. psidii from Taiwan and locating the type of $M$. psidii; Jan Dijksterhuis (CBS) for help with scanning electron microscopy; and Charity Ramasodi (University of Pretoria) as well as Arien van Iperen and Mieke Starink (CBS) for technical support. We also thank Aimee Hyten (USDA, Beltsville) for sequencing the ITS rDNA of the isolate from Taiwan. The research was financially supported by the National Research Foundation (NRF), members of the Tree Protection Cooperative Programme (TPCP) and the THRIP initiative of the department of Trade and Industry, South Africa.

\section{LITERATURE CITED}

Ahrazem O, Gómez-Miranda B, Prieto A, Barasonaií I, Bernabé M, Leal JA. 1999. Structural characterization of a cell wall polysaccharide from Penicillium vermoesenii: chemotaxonomic application. Can J Bot 77:961-968.

- Prieto A, Gómez-Miranda B, Bernabé M, Leal JA. 2001. Comparison of cell-wall polysaccharides from Nectria cinnabarina with those from the group of Nectria with Sesquicillium anamorphs. Microbiology 147: 1839-1849.

Anonymous. 1987. Guava wilting disease: the Cape scenario. CSFRI Information Bulletin 179:1-2.

2001. CBS. List of cultures. Filamentous fungi and yeasts, bacteria, plasmids, phages. 35th ed. Utrecht: Centraalbureau voor Schimmelcultures. 687 p.

Aragaki M, Broschat TK, Chase AR, Ohr HD, Simone GW, Whida J. 1991. Pink rot (Gliocladium blight). In Chase AR, Broschat TK, eds. Diseases and disorders of ornamental palms. St. Paul, Minnesota: APS Press. p 24-25.

Artjariyasripong S, Mitchell JI, Hywel-Jones NL, Jones EBG. 2001. Relationship of the genus Cordyceps and related genera, based on parsimony and spectral analysis of partial $18 \mathrm{~S}$ and $28 \mathrm{~S}$ ribosomal gene sequences. Mycoscience 42:503-517.

Benade E, Kemp GHJ, Wingfield MJ, Kock JFL. 1991. Comparison of Acremonium diospyri with the guava wilt pathogen in South Africa. Phytophylactica 137:98.

Berbee ML, Yoshimura A, Sugiyama, Taylor JW. 1995. Is Penicillium monophyletic? An evaluation of phylogeny in the family Trichocomaceae from 18S, 5.8S and ITS ribosomal DNA sequence data. Mycologia 87:210-222. 
Bills GF, Polishook JD, Goetz MA, Sullivan RF, White JF Jr. 2002. Chaunopycnis pustulata sp. nov., a new clavicipitalean anamorph producing metabolites that modulate potassium ion channels. Mycol Prog 1:3-18.

Biourge P. 1923. Les moisissures du groupe Penicillium Link. Étude monographique. La Cellule 33:7-331.

Bliss DE. 1938. The Penicillium disease of ornamental palms. Fifth Western Shade Tree Conf. Proc. p 20-27.

Cole GT, Samson RA. 1979. Patterns of development in conidial fungi. London: Pitman. 190 p.

Crandall BS. 1945. A new species of Cephalosporium causing persimmon wilt. Mycologia 37:495-498.

— Baker WL. 1950. The wilt disease of American persimmon caused by of Cephalosporium diospyri. Phytopathology 40:307-325.

de Hoog GS, Gerrits van den Ende AHG. 1998. Molecular diagnostics of clinical strains of filamentous Basidiomycetes. Mycoses 41:183-189.

Dijksterhuis J, Harder W, Wyss U, Veenhuis M. 1991. Colonization and digestion of nematodes by the endoparasitic nematophagous fungus Drechmeria coniospora. Mycol Res 95:873-878.

Domsch KH, Gams W, Anderson TH. 1980. Compendium of soil fungi. London: Academic Press. 859 p.

Durrell LW. 1963. Notes on Cephalosporium species. Colorado State University, Fort Collins. 28 p.

Farr DF, Bills GF, Chamuris GP, Rossman AY. 1989. Fungi on plants and plant products in the United States. Minnesota: APS Press. 1252 p.

Gams W. 1971. Cephalosporium-artige Schimmelpilze (Hyphomycetes). Gustav Fischer: Stuttgart. 262 p.

- 1975. Cephalosporium-like hyphomycetes: some tropical species. Trans Br mycol Soc 64:389-404.

- 1978. Connected and disconnected chains of phialoconidia and Sagenomella gen. nov. segregated from Acremonium. Persoonia 10:97-112.

— Hoekstra ES, Aptroot A, eds. 1998a. CBS Course of mycology. 4th ed. Baarn: Centraalbureau voor Schimmelcultures. $165 \mathrm{p}$.

—, O’Donnell K, Schroers H-J, Christensen M. 1998b. Generic classification of some more hyphomycetes with solitary conidia borne on phialides. Can J Bot 76:15701583.

Gerlach W, Nirenberg HI. 1982. The genus Fusarium-a pictorial atlas. Mitt Biol Bundesanst Land-Forstw Berlin-Dahlem 209:1-406.

Grech NM. 1985. The first report of guava rapid death syndrome caused by Septofusidium sp. in South Africa. Plant Dis 698:726.

. 1990. Guava wilting disease in Levubu. Citrus and Sub-tropical Fruit Research Institute Information Bulletin 218:8.

Haugland RA, Vesper SJ, Harmon SM. 2001. Phylogenetic relationships of Memnoniella and Stachybotrys species and evaluation of morphological features for Memnoniella species identification. Mycologia 93:54-65.

Hywel-Jones NL. 1993. Torrubiella luteorostrata (Ascomycotina: Clavicipitales): a pathogen of scale insects and its association with Paecilomyces cinnamomeus with a note on Torrubiella tenuis. Mycol Res 96:1126-1130.
Jeannmougin F, Thompson JD, Gouy M, Higgins DG, Gibson TJ. 1998. Multiple sequence alignment with Clustal X. Trends Biochem Sci 23:403-405.

Kornerup A, Wanscher JH. 1978. Methuen handbook of colour. London: Eyre Methuen. 252 p.

Kurosawa E. 1926. Guava Tachigare Byd. Rep Taiwan Museum 83:47-61.

Leu LS, Kao CW, Wang CC, Liang WJ, Hsieh SPY. 1979. Myxosporium wilt of guava and its control. Plant Dis Rep 63:1075-1077.

López-Llorca LV, Orts S. 1994. Histopathology of infection of the palm Washingtonia filifera with the pink bud rot fungus Penicillium vermoesenii. Mycol Res 98:11951199.

Nirenberg HI. 1976. Untersuchungen über die morphologische und biologische Differenzierung in der Fusarium-Sektion Liseola. Mitt Biol Bundesanst Land-Forstw Berlin-Dahlem 169:1-117.

_ O'Donnell K. 1998. New Fusarium species and combinations within the Gibberella fujikuroi species complex. Mycologia 90:434-458.

O'Donnell K. 1993. Fusarium and its near relatives. In: Reynolds DR, Taylor JW, eds. The fungal holomorph: mitotic, meiotic and pleomorphic speciation in fungal systematics. Wallingford, England: C.A.B. International. p 225-233.

, Cigelnik E. 1997. Two divergent intragenomic rDNA ITS2 types within a monophyletic lineage of the fungus Fusarium are nonorthologous. Mol Phylo Evol 7:103-116.

and phylogeography of the Gibberella fujikuroi species complex. Mycologia 90:465-493.

—, Gray LE. 1995. Phylogenetic relationships of the soybean sudden death syndrome pathogen Fusarium solani $\mathrm{f}$. sp. phaseoli inferred from rDNA sequence data and PCR primers for its identification. Mol PlantMicrobe Interact 8:709-716.

Ogawa H, Yoshimura A, Sugiyama J. 1997. Polyphyletic origins of species of the anamorphic genus Geosmithia and the relationships of the cleistothecial genera: evidence from 18S, 5S and 28S rDNA sequence analyses. Mycologia 89:756-771.

Pitt JI. 1979. Geosmithia gen. nov. for Penicillium lavendulum and related species. Can J Bot 57:2021-2030.

Põldmaa K, Larsson E, Kõljalg U. 1999. Phylogenetic relationships in Hypomyces and allied genera, with emphasis on species growing on wood-decaying homobasidiomycetes. Can J Bot 77:1756-1768.

Raper K, Thom C. 1949. A manual of Penicillia. The Baltimore, Maryland: Williams and Wilkins Co.

Rehner SA, Samuels GJ. 1994. Taxonomy and phylogeny of Gliocladium analysed from nuclear large subunit ribosomal DNA sequences. Mycol Res 98:625-634.

— pocreales: a teleomorph gene phylogeny and the status of their anamorphs. Can J Bot 73:S816-S823.

Reynolds JE. 1964. Gliocladium disease of palm in Dade County, Florida. Pl Dis Rep 48:718-720.

Rossman AY, Samuels GJ, Rogerson CT, Lowen R. 1999. 
Genera of Bionectriaceae, Hypocreaceae and Nectriaceae (Hypocreales, Ascomycetes). Stud Mycol 42:1-260.

-, McKemy JM, Pardo-Schultheiss RA, Schroers H-J. 2001. Molecular studies of the Bionectriaceae using large subunit rDNA sequences. Mycologia 93:100-110.

Samson RA. 1974. Paecilomyces and some allied Hyphomycetes. Stud Mycol 6:1-119.

Samuels GJ. 1973. The genus Macbridella with notes on $\mathrm{Ca}$ lostilbe, Herpotrichia, Phaeonectria, and Letendraea. Can J Bot 51:1275-1283.

1989. Nectria and Penicillifer. Mycologia 81:347-355.

, Brayford D. 1994. Species of Nectria (sensu lato) with red perithecia and striate ascospores. Sydowia 46: 75-161.

- Seifert KA. 1981. Two new species of Nectria with Stilbella and Mariannaea anamorphs. Sydowia 43:249263.

Schoeman MH, Benade E, Wingfield MJ. 1997. The symptoms and cause of Guava Wilt in South Africa. J of Phytopathol 145:37-41.

Schroers H-J. 2001. A monograph of Bionectria (Ascomycota, Hypocreales, Bionectriaceae) and its Clonostachys anamorphs. Stud Mycol 46:1-214.

- Samuels GJ, Seifert K, Gams W. 1999. Classification of the mycoparasite Gliocladium roseum in Clonostachys as C. rosea, its relationship to Bionectria ochroleuca, and notes on other Gliocladium-like fungi. Mycologia 91: 365-385.

Seaver FJ. 1910. Notes on North American Hypocreales III. Two new species with studies of their life histories. Mycologia 2:175-182.

Seifert KA. 1985. A monograph of Stilbella and some allied Hyphomycetes. Stud Mycol 27:1-235.
Smith G. 1962. Some new and interesting species of microfungi. 3. Trans Br mycol Soc. 45:387-394.

Subramanian CV. 1956. Hyphomycetes-II. J Indian Bot Soc 35:446-494.

- 1971. Hyphomycetes, an account of Indian species, except Cercosporae. New Delhi: Indian Council of Agricultural Research. 930 p.

Sung GH, Spatafora JW, Zare R, Hodge KT, Gams W. 2001. A revision of Verticillium sect. Prostrata. II. Phylogenetic analyses of SSU and LSU nuclear rDNA sequences from anamorphs and teleomorphs of the Clavicipitaceae. Nova Hedwigia 72:311-328.

Sutton BC. 1977 Coelomycetes VI. Nomenclature of generic names proposed for Coelomycetes. Mycol Pap 141:1253.

Swofford DL. 2002. PAUP*. Phylogenetic Analysis Using Parsimony (*and other methods). 4.0b.4a. Massachusetts, Sunderland: Sinauer Associates.

Thom C. 1930. The Penicillia. Baltimore: Williams and Wilkins. 644 p.

Vilgalys R, Hester M. 1990. Rapid genetic identification and mapping of enzymatically amplified ribosomal DNA from several Cryptococcus species. J Bacteriol 172:42384246.

von Höhnel F. 1915. Beiträge zur Mykologie 9. Über die Gattung Myxosporium Link. Z Gärungsphysiol 5:191215.

White TJ, Bruns T, Lee S, Taylor J. 1990. Amplification and direct sequencing of fungal ribosomal RNA genes for phylogenetics. In: Innis MA, Gelfand DH, Sninsky JJ, White TJ, eds. PCR protocols: a guide to methods and amplifications. San Diego, California: Academic Press. p 315-322. 